Review

\title{
Predominant mycotoxins, mycotoxigenic fungi and climate change related to wine
}

\author{
R. Russell M. Paterson ${ }^{\mathrm{a}, *}$, Armando Venâncio ${ }^{\mathrm{a}}$, Nelson Lima ${ }^{\mathrm{a}}$, Michèle Guilloux-Bénatier ${ }^{\mathrm{b}}$, \\ Sandrine Rousseaux ${ }^{\mathrm{b}}$ \\ a Centre of Biological Engineering, Campus de Gualtar, University of Minho, 4710057 Braga, Portugal \\ ${ }^{\mathrm{b}}$ Université Bourgogne Franche-Comté, AgroSup Dijon, PAM UMR A 02.102, F-21000 Dijon, France
}

\section{A R T I C L E I N F O}

\section{Keywords:}

Aspergillus

Fumonisin

Ochratoxin a

Aflatoxin

Climate change

\begin{abstract}
A B S T R A C T
Wine is a significant contributor to the economies of many countries. However, the commodity can become contaminated with mycotoxins produced by certain fungi. Most information on mycotoxins in wine is from Spain, Italy and France. Grapes can be infected by mycotoxigenic fungi, of which Aspergillus carbonarius producing ochratoxin A (OTA) is of highest concern. Climate is the most important factor in determining contamination once the fungi are established, with high temperatures being a major factor for OTA contamination: OTA in wine is at higher concentrations in warmer southern Europe than northern. Contamination by fumonisins is a particular concern, related to Aspergillus niger producing these compounds and the fungus being isolated frequently from grapes. Aflatoxins can be present in wine, but patulin is seldom detected. Alternaria mycotoxins (e.g. alternariol) have been frequently observed. There are indications that T-2 toxin may be common. Also, the combined effects of mycotoxins in wine require consideration. No other mycotoxins are currently of concern. Accurate fungal identifications and mycotoxin detection from the fungi are important and a consideration of practical methods are required. There is a diversity of wines that can be contaminated (e.g. red, white, sweet, dry and fortified). The occurrence of OTA is higher in red and sweet than white wines. Steps to control mycotoxins in wine involve good agriculture practices. The effect of climate change on vines and mycotoxins in wine needs urgent consideration by well-constructed modelling studies and expert interpretation of existing data. Reliable models of the effect of climate change on vines is a priority: the health of vines affects mycotoxin contamination. A modelling study of OTA in grapes at higher temperatures over 100 years is required. Progress has been made in reducing OTA in wine. The other mycotoxins require consideration and the effects of climate change will become crucial.
\end{abstract}

\section{Introduction}

Wine is defined by the Organisation Internationale de la Vigne et du Vin (OIV) (http://www.oiv.int; 10.07.17) as being obtained from grape berries (OIV, 2016a). The commodity is important, contributing greatly to the economies of countries such as France, Italy, Spain, USA, Argentina, and South Africa, which are the primary wine producers and in that order (OIV, 2016b). France was the highest consuming country followed by Italy (Mateo, Medina, Mateo, Mateo, \& Jiménez, 2007), although OIV (2016b) places the USA as the highest for the 2014 vintage.

The quality of wine includes considering the microbiological and chemical purity by avoiding contamination with compounds such as mycotoxins. Grapes are susceptible to fungal diseases and in some cases the fungi produce mycotoxins (Paterson \& Lima, 2010a;
Paterson \& Lima, 2010b; Pena, Cerejo, Silva, \& Lino, 2010). Freire et al. (2017) discovered a correlation between (a) physiochemical qualities of wine grapes such as pectin content and total sugars, and (b) the presence of all fungi isolated, except for Aspergillus flavus. Mycotoxins are fungal secondary metabolites that contaminate crops from fungal growth and are associated with causing human and animal diseases. A list of mycotoxigenic fungi and the chemical structures of some mycotoxins are provided in Table 1 and Fig. 1 respectively.

Many countries have established regulations for control of mycotoxins in food (Venâncio \& Paterson, 2007) and there is much toxicological information regarding mycotoxins (Liu \&Wu, 2010; Paterson \& Lima, 2010b) which are relevant to wine. This current review concentrates on the most important mycotoxins referred to as conventional mycotoxins, rather than the large list of potential mycotoxins (Paterson \& Lima, 2017). The most important mycotoxin in wine

\footnotetext{
* Corresponding author.

E-mail address: russell.paterson@deb.uminho.pt (R.R.M. Paterson).
} 
Table 1

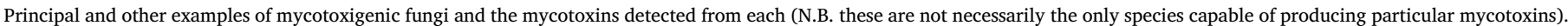

\begin{tabular}{|c|c|c|}
\hline Filamentous fungi & Mycotoxins & Reference \\
\hline \multicolumn{3}{|l|}{ Aspergillus } \\
\hline A. carbonarius, A. westerdijkiae, A. niger & Ochratoxin A & $\begin{array}{l}\text { Cabañes et al. (2002); Medina, Mateo, Lo, and Valle-algarra (2005); Díaz, Torres, Vega, } \\
\text { and Latorre (2009); Paterson, Lima, and Taniwaki (2014); Garmendia and Vero (2016); } \\
\text { Freire et al. (2017); Kizis, Natskoulis, Nychas, and Panagou (2014); Barberis, Merlera, } \\
\text { Reynoso, Chulze, and Torres (2014) }\end{array}$ \\
\hline A. niger & Fumonisins B2 and B4 & Logrieco et al. (2009) \\
\hline A. parasiticus & Aflatoxin B1, B2, G1, G2 & Rodrigues, Venâncio, and Lima (2009) \\
\hline A. flavus & $\begin{array}{l}\text { Aflatoxin production strain } \\
\text { dependent }\end{array}$ & Rodrigues et al. (2009) \\
\hline \multicolumn{3}{|l|}{ Byssochlamys } \\
\hline B. fulva, B. nivea & Patulin & Wright (2015) \\
\hline \multicolumn{3}{|l|}{ Fusarium } \\
\hline F. cerealis & Nivalenol & De Lucca and Walsh (2015) \\
\hline F. culmorum $F$. graminearum & Deoxynivalenol, Nivalenol & De Lucca and Walsh (2015) \\
\hline F. equiseti & Zearalenone & De Lucca and Walsh (2015) \\
\hline F. poae & Nivalenol & De Lucca and Walsh (2015) \\
\hline F. sporotrichioides & $\mathrm{T}-2$ toxin & De Lucca and Walsh (2015) \\
\hline $\begin{array}{l}\text { F. verticillioides }(=F . \text { moniliforme }), F . \text { globosum, } F \text {. } \\
\quad \text { nygami, } F . \text { proliferatum }\end{array}$ & Fumonisin B1 & Mogensen, Møller, Von Freiesleben, et al. (2011) \\
\hline \multicolumn{3}{|l|}{ Penicillium } \\
\hline P. expansum & Patulin & Frisvad and Samson (2004); Wright (2015) \\
\hline$P$. verrucosum, $P$. nordicum & Ochratoxin A & Frisvad and Samson (2004) \\
\hline
\end{tabular}

is ochratoxin A (OTA) (Amézqueta, González-Peñas, MurilloArbizu, \& López de Cerain, 2009; Varga \& Kozakiewicz, 2006). Wine consumption is an important source of OTA (Coronel, Marín, CanoSancho, Ramos, \& Sanchis, 2012) and is the second most frequent source in the European diet (Miraglia \& Brera, 2002).

The objectives of this paper are to (a) review the literature on the important mycotoxins, (b) establish the producing fungi, (c) suggest amelioration strategies, and (d) discuss how climate change will affect mycotoxins in wine.

\section{Ochratoxin A and producing fungi from grapes}

OTA is a cyclic, chlorinated pentaketide dihydroisocoumarin derivate linked to L- $\beta$-phenylalanine by an amide bond and which has been detected from many agricultural products. Several nephropathies affecting animals and humans have been attributed to OTA. It is the etiological agent of Danish porcine nephropathy and renal disorders in other animals and is often cited as the causative agent of Balkan endemic nephropathy in humans, although other compounds may be involved. The mycotoxin exhibits immunosuppressive, teratogenic, hepatotoxic and carcinogenic properties. OTA may cause genotoxic affects, although the evidence remains unclear and OTA-mediated DNA-adduct formation has been demonstrated. The compound may be involved with chronic interstitial nephropathy, urothelial tumours and testicular cancer: IARC classify OTA as a possible human carcinogen (Varga, Kocsubé, Szigeti, Baranyi, \& Tóth, 2015).

The predominant OTA producing fungi in grapes are from the genus Aspergillus (Dachery, Manfroi, Berleze, \&Welke, 2016; Leong, Hocking, \& Scott, 2006a; Leong, Hocking, \& Scott, 2006b; Rousseaux, Diguta, Radoï-Matei, Alexandre, \& Guilloux-Bénatier, 2014) (Table 1) and particularly A. carbonarius and A. niger (Frisvad et al., 2007). Samson et al. (2014) demonstrated that A. tubingensis and A. niger/ welwitschiae clades each contain strains of high similarity, but the clades are well separated from each other as determined by the calmodulin sequences. These two clades formed the $A$. niger aggregate clade. The $A$. carbonarius clade consisted of more heterogeneous strains perhaps forming two clusters within the clade. These three clades form the biseriate Aspergillus species, together with a forth clade A. heteromorphus, consisting of only two strains. A. heteromorphus has not been reported from grapes in the current authors' review of the literature.

OTA is produced in higher quantities by $A$. carbonarius than $A$. niger in general and in vitro, although some strains of $A$. niger can be higher producers than $A$. carbonarius (Perrone et al., 2006). A. tubingensis were lower producers still on average, but equally some strains were higher producers than a few of $A$. carbonarius. Using different conditions may affect the relative production of OTA of strains of these species. A study of grape berries from 107 vineyards in different European countries led to the identification of four main populations of aspergilli which included A. aculeatus, A. japonicus, A. uvarum, A. ellipticus, A. heteromorphus, A. carbonarius, A. ibericus, A. brasiliensis, A. niger, A. foetidus and $A$. tubingensis (Perrone et al., 2007), a small proportion of which are OTA producers. Studies of black aspergilli occurring in wine grapes and vineyards from predominantly the Mediterranean, South America and Australia have clarified that the (a) biseriate species aggregate, $A$. niger and A. carbonarius, and (b) uniseriate species, A. aculeatus and A. japonicus are prevalent (Garmendia \& Vero, 2016). Freire et al. (2017) isolated OTA-producing $A$. carbonarius from Brazilian grapes.

The frequency of ochratoxigenic strains of $A$. carbonarius and $A$. niger "aggregate" on grapes were similar in the Mediterranean countries and Australia (Leong et al., 2006a; Leong et al., 2006b; Leong, Hocking, \& Scott, 2007) and a decrease in black Aspergillus spp. was apparent in cool regions such as Tasmania (Hocking, Leong, Kazi, Emmett, \& Scott, 2007). However, A. niger was reported as the main ochratoxigenic species on grapes in South America (Da Rocha Rosa et al., 2002; Magnoli, Violante, Combina, Palacio, \& Dalcero, 2003). The $A$. niger aggregate group of strains was also the most frequent from Argentinean grapes, with $27 \%$ of the isolates producing detectable OTA (Perrone et al., 2007). A study in Uruguay indicated that (a) A. uvarium (uniseriate) and A. welwitschiae were prevalent and (b) A. carbonarius was undetected (Garmendia \& Vero, 2016). Barberis et al. (2014) isolated predominantly $A$. tubingensis amongst others in Argentinian vineyards. A. carbonarius was isolated to a lesser degree. All A. carbonarius produced OTA which was not detected in the other taxa.

There appears an association between the isolation of $A$. carbonarius from grape berries of southern Europe and the higher concentrations of OTA in wines (Mateo et al., 2007). A. carbonarius is prevalent in southern parts of France, Italy, Portugal and Greece, although A. tubingensis and $A$. niger proved the dominant species elsewhere (Perrone et al., 2007). A. carbonarius dominated the mycotoxigenic fungi in Portugal (Serra, Lourenço, Alípio, \& Venâncio, 2006; Serra, Mendonça, \& Venâncio, 2006). OTA producing black aspergilli were isolated mainly in southern Portugal which has hot and dry summers (Serra, Abrunhosa, Kozakiewicz, \& Venâncio, 2003), perhaps a factor in their frequent isolation (see below). OTA producing fungi were 
<smiles></smiles>

Aflatoxin $B_{1}\left(A F B_{1}\right)$

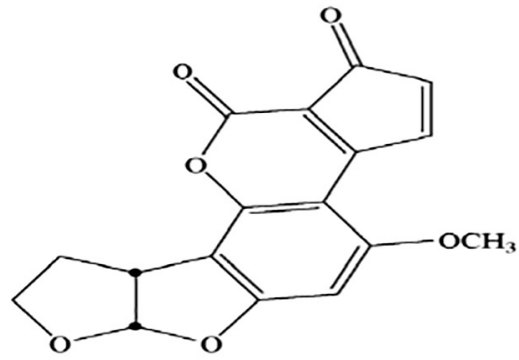

Aflatoxin $\mathrm{B}_{2}\left(\mathrm{AFB}_{2}\right)$

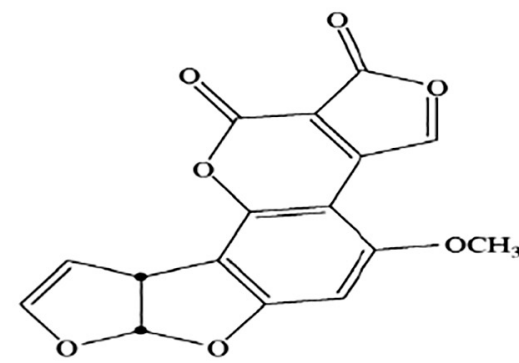

Aflatoxin $G_{1}\left(A F G_{1}\right)$<smiles></smiles>

Aflatoxin $\mathrm{G}_{2}\left(\mathrm{AFG}_{2}\right)$<smiles>COc1cc(O)c2c(c1)C1=CC(O)C(O)CC1(C)OC2=O</smiles>

Altenuene (ALT)

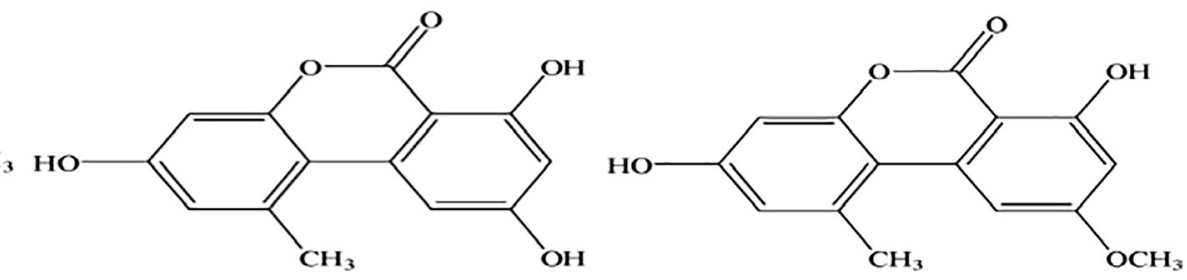

Alternariol $(\mathrm{AOH})$

Alternariol methyl ether (AME)<smiles>CCC(C)C1NC(=O)C(C(C)=O)=C1O</smiles>

Tenuazonic acid<smiles>O=C1CC[C@@]2(O)c3c4ccc(O)c3C(=O)C[C@@H](O)[C@@H]2c2c-4ccc(O)c21</smiles>

Altertoxin-I<smiles>CC1Cc2c(Cl)cc(C(=O)NC(Cc3ccccc3)C(=O)O)c(O)c2C(=O)O1</smiles>

Ochratoxin-A (OTA)<smiles>O=C1C=C2CC(O)OC=C2O1</smiles>

Patulin (PAT)

Fig. 1. Chemical structures of some well-known mycotoxins.

evaluated in the North, centre and South of Italy and A. carbonarius was found predominantly in the south, while $A$. niger was in the central and northern regions (Lucchetta et al., 2010). Predominantly A. niger aggregate strains were isolated from the vine environment in southern Italy, and ca. 50\% produced OTA, mainly at low concentrations. A. carbonarius was identified at low frequency, with most isolates producing OTA at high concentrations (Oliveri, Bella, Tessitori, Catara, \& Rosa, 2016). A. tubinogensis and A japonicus were isolated at low levels and OTA was detected in at least one strain of each, although A. japonicus is not considered an OTA producer (Perrone, Logrieco, \& Frisvad, 2017). In Greece, 128 strains of $A$. carbonarius, $A$. tubingensis, $A$. japonicus and A. ibericus were isolated, with 4 A. niger aggregate strains. A. carbonarius and $A$. tubingensis were the main representative species. Of $44 A$. tubingensis, 1 produced detectable OTA under the conditions employed. Most of the A. carbonarius produced OTA at high levels. OTA was not detected from A. niger aggregate and A. iberius (Kizis et al., 2014).

A. carbonarius was the most prevalent OTA fungus and was found in two regions in Spain (García-Cela, Crespo-Sempere, Gil-Serna,
Porqueres, \& Marin, 2015). A. tubingensis and A. niger were also isolated and at least some strains of all the species produced detectable OTA. Garcia-Cela, Crespo-Semprre, Ramos, Sanchis, and Marin (2014) described the ecophysiological properties of $A$. carbonarius, A. tubingensis and $A$. niger from Spanish vineyards. OTA-producing black aspergilli were isolated from southern Hungary (Varga, Kiss, Mátrai, \& Téren, 2005) and Mikusová, Ritieni, Santini, Juhasová, and Srobárová (2010) detected numerous OTA producing aspergilli from Slovakian grapes. (Further relevant information on producing fungi can be found in Section 2.2 below.)

Zhang et al. (2016) discovered the novel OTA-producing fungi, Talaromyces rugulosus, Penicillium commune, Penicillium rubens and the uniseriate species, Aspergillus aculeatus from grapes of three organic vineyards in China, in a unique report from this country. However, Perrone et al. (2017) questioned the data and recommended criteria to establish the correct assessments. The current authors suggest it would be difficult for many ordinary laboratories to undertake the characterization criteria due to their complexity (see General discussion).

Similarly, reports of OTA production by A. tubingensis were not 
Table 2

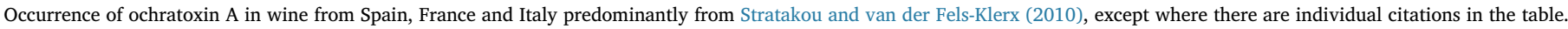

\begin{tabular}{|c|c|c|c|c|c|}
\hline Country & Year & Colour & No. of samples & $\operatorname{Max}\left(\mu g \mathrm{~L}^{-1}\right)$ & Mean $\left(\mu g L^{-1}\right)$ \\
\hline France north & 1997-99 & Red & 68 & 0.78 & 0.061 \\
\hline France south & 1997-99 & Red & 40 & 0.47 & 0.07 \\
\hline \multirow[t]{7}{*}{ France } & 1998 & "wine" & 29 & 0.19 & 0.038 \\
\hline & 1998-99 & "wine" & 104 & 1.64 & 0.05 \\
\hline & $2000-6$ & White & 7 & 0.54 & 0.072 \\
\hline & & Rosé & 3 & 0.54 & 0.223 \\
\hline & & Red & 20 & 3.24 & 0.912 \\
\hline & $\begin{array}{l}\text { 2006-9 (Remiro, Irigoyen, González-Peñas, Lizarraga, \& López de } \\
\text { Cerain, 2013) }\end{array}$ & Red & 12 & 0.088 & 0.039 \\
\hline & Purchased 2009 (Quintela, Villarán, Armentia, \& Elejalde, 2012 & Red & 14 & 0.237 (of the 13 positives) & 0.058 (of the 13 positives) \\
\hline \multirow[t]{11}{*}{ Italy } & 1998 & Red & 18 & 3.17 & 0.66 \\
\hline & 1999 & Red & 115 & 15.61 & 2.1 \\
\hline & & White & 21 & 8.86 & 0.57 \\
\hline & & Rosé & 4 & 0.26 & 0.13 \\
\hline & 1997-1998 & Red & 38 & 7.63 & 1.21 \\
\hline & & White & 9 & 0.97 & 0.16 \\
\hline & & Rosé & 8 & 1.15 & 0.63 \\
\hline & 2005-12 (Giovannoli, Passini, Nardo, Anfossi, \& Baggiani, 2014) & Red & 17 & $0.941^{\mathrm{a}}\left(0.886^{\mathrm{b}}\right)$ & $0.364^{\mathrm{a}}\left(0.336^{\mathrm{b}}\right)$ \\
\hline & 2005-8 (Remiro et al., 2013) & Red & 12 & 0.286 & 0.054 \\
\hline & Purchased 2009 (Quintela et al., 2012) & Red & 8 & 0.353 & 0.144 \\
\hline & (Prelle, Spadaro, Denca, Garibaldi, \& Gullino, 2013) & Red & 30 & $\begin{array}{l}2.69 \text { from the } 2 \text { positive } \\
\text { samples. }\end{array}$ & $\begin{array}{l}2.34 \text { from the } 2 \text { positive } \\
\text { samples }\end{array}$ \\
\hline North Italy & 1997-99 & Red & 8 & 0.54 & 0.102 \\
\hline \multirow[t]{26}{*}{ South Italy } & 1997-99 & Red & 43 & 2.55 & 0.193 \\
\hline & & Red & 20 & 3.31 & 1.153 \\
\hline & 1999 & Red & 60 & & 0.4 \\
\hline & 1992-99 & Red & 184 & 15.6 & 1.565 \\
\hline & 1999 & White & 20 & 8.864 & 0.596 \\
\hline & & Rosé & 4 & 0.283 & 0.122 \\
\hline & & Red & 27 & 7.63 & 0.131 \\
\hline & & red home made & 11 & 4.42 & 1.185 \\
\hline & & Rosé & 6 & 1.15 & 0.804 \\
\hline & & Rosé home made & 2 & 0.64 & 0.525 \\
\hline & & White & 7 & 0.06 & 0.045 \\
\hline & & $\begin{array}{l}\text { White home } \\
\text { made }\end{array}$ & 2 & 0.97 & 0.535 \\
\hline & 1998-99 & Red & 96 & 3.177 & 0.419 \\
\hline & $2000-6$ & "wine" & 80 & 2.9 & \\
\hline & & "wine" & 150 & 5.2 & \\
\hline & & Red & 23 & 1.34 & 0.348 \\
\hline & & Red & 6 & 2.933 & 1.802 \\
\hline & & Rosé & 2 & 1.348 & 1.348 \\
\hline & & White & 18 & 0.456 & 0.264 \\
\hline & & White & 10 & 0.289 & 0.144 \\
\hline & & White & 27 & 0.02 & 0.015 \\
\hline & & Red & 36 & 0.1 & 0.041 \\
\hline & 1999-2006 & "wine" & 1166 & 7.5 & 0.28 \\
\hline & $2004-06$ & "Wine" & 10 & 1.7 & \\
\hline & $2006-2010$ & White & 204 & 1.36 & 0.086 \\
\hline & & Red & 1002 & 2.63 & 0.121 \\
\hline \multirow[t]{5}{*}{ Spain } & 1998 & Red & 14 & 0.193 & 0.133 \\
\hline & & White & 6 & 0.192 & 0.192 \\
\hline & 2006-2009 (Remiro et al., 2013) & Red & 12 & 0.104 & 0.033 \\
\hline & $\begin{array}{l}\text { 2004-2008 (Remiro, González-peñas, Lizarraga, López, \& Cerain, } \\
\text { 2012) }\end{array}$ & Red & 51 & 0.070 & 0.011 \\
\hline & Purchased 2009 (Quintela et al., 2012) & Red & 2 & 0.138 & 0.101 \\
\hline
\end{tabular}

\footnotetext{
a Molecularly imprinted solid phase extraction

b Immune affinity column extraction.
}

confirmed (Storari et al., 2012; Storari, Bigler, Gessler, \& Broggini, 2012) and should perhaps be analysed as discussed in Perrone et al. (2017) before being accepted as OTA producers. The presence of metabolites with retention times similar to the OTA signal in the A. tubingensis extracts or background noise from the growth media may be reasons for the misinterpretation of the chromatograms obtained by HPLC-FLD.

The role of OTA producing penicillia in contaminating wine is of interest, although isolation from grapes is considered infrequent. However, Mikusová et al. (2010) isolated OTA-producing P. verrucosum from Slovakian grapes. Battilani, Giorni, and Pietri (2001) and Rousseaux et al. (2014) reported OTA-producing Penicillium species from grapes in northern Italy and France, suggesting they could be involved in OTA contamination. The production of OTA from Chinese penicillia (Zhang et al., 2016) requires confirmation (Perrone et al., 2017). In general, isolating OTA fungi from grapes should not exclude penicillia. 


\subsection{Environmental sources of ochratoxin A producing fungi}

The primary sources of $A$. carbonarius and A. niger in 6 Australian vineyards were soil and vine remnants on soil. They were isolated occasionally from fallen dried berries, dead canes, vine bark, dried bunch stems and dead cover crop trash, but were seldom from leaves (green and/or senescent), tendrils and green cover crop plants (Hocking et al., 2007). A. carbonarius conidia increased in air samples closer to the soil where a severe dust storm resulted in an increased of the fungus on grape bunches in Australia (Leong et al., 2006b; Leong, Hocking, Pitt et al., 2006) indicating how OTA could arise. Weeds were an important inoculum for $A$. niger in Argentinean vineyards (Chulze, Magnoli, \& Dalcero, 2006). Increased concentrations of A. carbonarius occurred in soil (a) $0-1 \mathrm{~cm}$ below the surface, compared to deeper soil, and (b) directly beneath vines, compared to the inter-row area (Hocking et al., 2007).

\subsection{How ochratoxin A occurs in wine}

The period between early veraison and harvest is critical for OTA contamination because abiotic and/or biotic damaged of berries allow access to ochratoxigenic fungi if present. Rot and OTA production commenced after veraison and increased with berry damage and ripeness. Damage to grapes can be caused by insects, fungal pathogens, excessive irrigation and rain damage (Leong et al., 2007). OTA is produced primarily when A. carbonarius infects berries before harvest (Mateo et al., 2007; Pitt, 1997) and the mycotoxin can be detected in grapes at the beginning of ripening and during harvest. OTA detected in grapes was from infection of berries by $A$. carbonarius and is concentrated in shrivelled and discoloured berries in Australia. Detection is also associated with strains from Aspergillus section Nigri being present on grapes (Blesa, Soriano, Moltó, \& Mañes, 2006). In addition, grape variety affects spoilage and growth of ochratoxigenic fungi in grapes (Blesa et al., 2006; Varga \& Kozakiewicz, 2006).

Grapes and derived products, such as juices and wines, are often contaminated with OTA (Anli \& Bayram, 2009). Interestingly, grapes from southern regions had a higher incidence of OTA reaching $2 \mathrm{mg}$ $\mathrm{L}^{-1}$ and a positive correlation was found between the number of black aspergilli found in grapes from Spanish vineyards and high temperatures (Bellí et al., 2005; Bellí, Marín, Coronas, Sanchis, \& Ramos, 2007). Isolation of aspergilli in cool and wet climates, such as parts of France, appears dependent on vintage (Bejaoui, Mathieu, Taillandier, \& Lebrihi, 2006; Diguta, Vincent, Guilloux-Benatier, Alexandre, \& Rousseaux, 2011; Guérin, Guyot, \& Vincent, 2007).

Black aspergilli more prevalent in the south of Spain (García-Cela et al., 2015). These are resistant to the hot and dry environments, and the presence of melanin in the fungal cells protects the fungi from UV irradiation (Hocking et al., 2007). Differences in growth boundaries from geographical origin in Spain were found within $A$. niger aggregate isolates. Conversely, A. carbonarius from the hotter and drier region grew and produced OTA at lower aw than other species. Low genetic diversity in A. carbonarius was observed and so intraspecific variability did not correlate with the geographical origin of the isolates nor their ability to produce OTA (Garcia-Cela et al., 2014). OTA-producing black aspergilli were isolated only from southern Hungary compared to the remainder of the country (Varga et al., 2005). Higher geographical representation of $A$. carbonarius was in southern Greece whereas $A$. tubingensis was predominant in northern regions (Kizis et al., 2014).

\subsection{Presence of ochratoxin $A$ in wine}

OTA is the only mycotoxin with legal limits in the European Union for wine and is $2 \mu \mathrm{g} \mathrm{kg}^{-1}$ (EC, 2005). Data concerning the occurrence in wines are provided from various countries (Blesa et al., 2006) and are also demonstrated in Table 2. In general, there is an increase in OTA in wines originating from southern Europe with warmer climates which influence fungal and OTA contamination. The presence of OTA was highest in wines from Italy, Spain and Greece where trends were assessed in the years 1995-1999, 2000-2006 and 2007-2010 (Stratakou \& van der Fels-Klerx, 2010). The EU statutory limits in 2005 for table wines, and the publication of a code of good practices (http:// www.ochra-wine.com; http://www.oiv.int/; 11/07/17) provided a stimulus for maintaining low concentrations.

The OTA concentration from 2000 to 2006 exceeded rarely the EU maximum allowed level (MAL) which was established subsequent to 2006. Espejo and Armada (2009) stated that OTA in wines produced in Europe varied between 0.01 and $3.41 \mu \mathrm{g} \mathrm{L}^{-1}$. Furthermore, a survey on 1470 wine samples demonstrated a mean OTA concentration of $0.36 \mathrm{ng}$ $\mathrm{g}^{-1}$, although an extremely high concentration of $15.6 \mu \mathrm{g} \mathrm{kg}^{-1}$ was reported in red wine from southern Europe (Miraglia \& Brera, 2002).

Italian wines produced from 2000 to 2006 contained between 0.009 and $2.947 \mu \mathrm{g} \mathrm{L}^{-1}$ OTA. Also, the wines from 2006 to 2008 showed higher OTA incidences but lower mean and maximum concentrations compared to pre-2004 ones (Spadaro, Lorè, Garibaldi, \& Gullino, 2010). The highest incidence and concentration was in red wines $(78.4 \%$ and $7.63 \mathrm{ng} \mathrm{mL}^{-1}$ ), followed by rosé, sweet and white, which is a different sequence to Spanish wines (see below). Sweet wine from Sicily is manufactured from grapes grown in the typical warmer climates and which have higher sugar content. Also, the over-ripening and the drying process of the grapes before fermentation conditions are responsible for the particular susceptibility of these to contamination by mycotoxin producing fungi. OTA and ochratoxin B were detected in $96.6 \%$ and $83.3 \%$ of the samples. The results indicated very low concentrations of OTA (Di Stefano et al., 2015), although the frequency was high.

Significant differences in OTA content in Rioja Alavesa Spanish wine from different regions revealed that lower rainfall and higher temperature regions produced highest OTA. No significant differences were found between types of wine in Quintela, Villarán, Armentia, and Elejalde (2011). The highest concentration was $15.25 \mu \mathrm{g} \mathrm{L}^{-1}$ in sweet wine, probably due to the production methods. The highest level was $4.5 \mu \mathrm{g} \mathrm{ml}^{-1}$ in table wine (Mateo et al., 2007; Stratakou \& van der FelsKlerx, 2010). Finally, OTA positive musts were only detected in southern Spanish vineyards compared to northern ones (García-Cela et al., 2015).

There are few data concerning French wine which is surprising considering their importance; however, 8 contaminated musts were found from 11 samples of French grapes with concentrations of OTA ranging from 0.010 to $0.461 \mu \mathrm{g} \mathrm{L}^{-1}$ (Sage, Krivobok, Delbos, SeigleMurandi, \& Creppy, 2002). French wines had lower maximum OTA concentrations than Italian and Spanish (Stratakou \& van der Fels-Klerx, 2010) and OTA was detected in 29 wines (0.01-0.27 $\mu \mathrm{g} \mathrm{L}^{-1}$ ), although $0.78 \mu \mathrm{g} \mathrm{L}^{-1}$ was detected in a red wine exported to Germany (Mateo et al., 2007).

Greek wines from 1999 to 2006 had 69\% positive samples but with low OTA concentrations: one sample contained the EU permitted maximum level and $91 \%$ had $<1.0 \mu \mathrm{g} \mathrm{L}^{-1}$. The higher concentrations were in wines from the south, and in sweet wines (Labrinea, Natskoulis, Spiropoulos, Magan, \& Tassou, 2011): red wines had high levels (Soufleros, Tricard, \& Bouloumpasi, 2003). Very high median and mean values of 0.466 and $0.833 \mu \mathrm{g} \mathrm{L}^{-1}$ were obtained for six table wines which were similar to values previously reported for sweet wines (Burdaspal \& Legarda, 2007).

Significant differences were observed in OTA content of Portuguese grapes between 2002 and 2003 which may have been related to temperature, although numbers of OTA producing fungi were similar between 2001 and 2003 (Serra et al., 2006; Serra et al., 2006). Sixty four Portuguese wines were negative for OTA, and it was present in 5 of 37 (13.5\%) other samples. Furthermore, OTA was detectable in $69(20.3 \%)$ of 340 Portuguese wines. Sixty seven wines had OTA levels below $0.5 \mu \mathrm{g} \mathrm{L}{ }^{-1}$ and one had a value of $2.1 \mu \mathrm{g} \mathrm{L}^{-1}$ (Ratola, Martins, \& Alves, 2004, 2005). The occurrence of OTA in Madeira wines was very low (Fernandes, Barros, \& Câmara, 2013). All samples of Turkish wines had 
detectable OTA and particularly high levels were in wines from 1998 to 2003 , with a maximum of $7.96 \mu \mathrm{g} \mathrm{L}^{-1}$ in 1998 . Values were slightly above $2 \mu \mathrm{g} \mathrm{L}^{-1}$ before 1998 and between 1 and $2 \mu \mathrm{g} \mathrm{L}{ }^{-1}$ after 2003 (Altiokka, Can, Atkoşar, \& Aboul-Enein, 2009).

Wines from North America had lower OTA levels than those from Europe and can be considered safe (Siantar et al., 2003; Soleas, Yan, \& Goldberg, 2001). Australian wines were low in OTA and do not pose a serious problem (Leong et al., 2006a; Leong et al., 2006b). Brazil, Argentina and Chile wines were better quality than European (Chulze et al., 2006; Terra, Prado, Pereira, Ematné, \& Batista, 2013) in this respect.

Wines from China were low in OTA and considered safe (Wu, Tan, Wang, \& Xu, 2011; Zhong et al., 2014). The mycotoxin was detected in 24 local South Africa samples where a "noble" (rot) wine had the highest level of $2.67 \mu \mathrm{g} \mathrm{L}{ }^{-1}$. There was a high incidence of contamination in red wines from northern Africa (Anli \& Bayram, 2009). All Croatian wine samples from the Adriatic coast were OTA-positive, while white wines from the north were uncontaminated (Varga \& Kozakiewicz, 2006). Organic wines were low in OTA levels (Comuzzo, Rauhut, Werner, Lagazio, \& Zironi, 2013) which may relate to improved management in the sorting of grapes and optimisation of vine growth.

In general, the occurrence data on OTA from 2006 onwards indicates the concentrations are decreasing in red wine with time which may relate to better agricultural practices because of the EU regulations and/or the effects of climate change (see later). The more recent conditions may be less suitable for the growth of ochratoxigenic fungi and OTA production. There have been reports of higher amounts of AF in some European crops because of the higher temperatures which may eventually replace OTA as the main problem (Battilani et al., 2016; Paterson \& Lima, 2017).

\subsection{Impact of climate}

The temperature range resulting in high OTA levels on grapes varies with fungal species: $A$. niger aggregate strains and individual $A$. carbonarius have optima of $30-35{ }^{\circ} \mathrm{C}$ and $25-30{ }^{\circ} \mathrm{C}$ respectively (Bellí, Marın, Sanchis, \& Ramos, 2004; Bellí, Ramos, Sanchis, \& Marín, 2007). Furthermore, the effect of temperature is most important at the moment of infestation (Bellí et al., 2007; Clouvel et al., 2008). Twenty one degrees Celsius appeared the lower limit below which fungal growth and OTA production were insufficient to result in critical levels of OTA in wine during the susceptible berry period (Clouvel et al., 2008; Paterson \& Lima, 2011a). High temperatures and relative humidity at the time of penetration of grapes by the fungi result in higher OTA content. Rainfall increases OTA by elevating relative humidity and causing damage to the grapes; berry splitting and high fungal colonization results if rain falls within the month before harvest, although high temperature must also occur (Stratakou \& van der Fels-Klerx, 2010). The concentration of OTA in wine detected at $30^{\circ} \mathrm{C}$ was higher than at $20^{\circ} \mathrm{C}$ in most cases (Anli \& Bayram, 2009). The highest relative humidity (100\%) led to maximum amounts of OTA, while no significant differences were found between $90 \%$ and $80 \%$. In summary, the conditions which favour OTA in wine are high temperatures reaching $30{ }^{\circ} \mathrm{C}$ and increased humidity, although dry condition cause problems occasionally: Lower than $21^{\circ} \mathrm{C}$ is safer, with the effect of moisture being more ambiguous (Paterson \& Lima, 2011a). However, high levels of OTA can result at lower temperatures related to the vines and grapes being infected with fungi with lower optimal temperatures for production and growth (Bellí et al., 2004; Bellí et al., 2007). Also, the effect of humidity can allow more OTA even at lower temperatures (Paterson \& Lima, 2011a): OTA production is increased at temperate temperature (ca. $20{ }^{\circ} \mathrm{C}$ ) and $0.96-0.98 \mathrm{a}_{\mathrm{w}}$ (Hocking et al., 2007; Medina et al., 2005; Medina, Jiménez, Mateo, \& Magan, 2007).

Samples from 11 vineyards from 4 winemaking regions in the North and South of Portugal were assessed for OTA (Serra et al., 2006; Serra et al., 2006). Significant differences were observed in OTA from grapes between 2002 and 2003 which may have been related to temperature. Small increases in temperature bring the grapes into the ranges where critical heat levels will be reached as demonstrated for French and Spanish wines (Paterson \& Lima, 2010a).

\subsection{Wine colour}

The occurrence of OTA is higher normally in red and sweet than white wines. (Sweet wines are consumed at lower rates in general and so are less significant in terms of risk.) Generally, white wines had lower OTA than rosé, which had lower concentrations than red indicating a relationship between maceration and the dissolution of OTA in the grape must: an increase of OTA of $20 \%$ during the maceration process has been reported (Fernandes, Ratola, Cerdeira, Alves, \& Venâncio, 2007). The production of ethanol during these initial stages may increase the solubility of OTA, contributing to higher OTA (Fernandes et al., 2007). Red wines were considered the second most prominent source of OTA intake at a rate of $15 \%$ contamination and OTA exposure could be doubled by moderate red wine consumption (Zimmerli \& Dick, 1996).

Levels of OTA as high as $15.6 \mu \mathrm{g} \mathrm{kg}^{-1}$ have been reported from wines in Southern Europe, with red frequently more contaminated than white from the same wine-growing region (Majerus, Hain, \& Kölb, 2000). The maximum levels of OTA were $15.6,8.86$ and $6.32 \mu \mathrm{g} \mathrm{kg}^{-1}$ for red, white and rosé wines respectively (Miraglia \& Brera, 2002). Pena et al. (2010) found OTA in nine (26\%) and three (12\%) red and white wine samples respectively, where one red and white wine sample had contamination levels at 1.23 and $2.4 \mu \mathrm{L} \mathrm{L}^{-1}$ respectively. Hence, in this case the white wine had the higher concentration.

\subsection{Fortified and overripe/dehydrated grape wines}

It is necessary to differentiate between wines of (a) standard and (b) high alcohol concentrations such as (a) table wines (e.g. Chablis, Rioja) and (b) fortified wines (e.g. Port, Vermouth), respectively when considering mycotoxin contamination. Also, wines from overripe and dehydrated grapes (EC, 1999) require consideration (Valero, Marín, Ramos, \& Sanchis, 2008). Only wines at $<15 \%$ alcohol are subject to the EU regulation limiting OTA of $2.0 \mu \mathrm{gg}^{-1}$ wine (EC, 2005, 2006). Fortified wines are those where ethanol is added to above 15\%. OIV did not differentiate between table and fortified wines when they recommended a maximum level of $2.0 \mu \mathrm{g}$ OTA $\mathrm{L}^{-1}$ wine, unlike the situation for the EU regulation (EC, 2006).

A. carbonarius is probably responsible for OTA in liqueur wines in part because it is very invasive even without skin damage (Samson et al., 2007). Also, many sweet wines are produced after sun drying of grapes where they are subjected to climatic conditions favouring aspergilli (Ruíz Bejarano, Rodríguez, \& Garcia, 2010). Sweet wine production, involving partial dehydration of grapes in the sun may allow fungal growth and higher OTA (Magan \& Aldred, 2005). For example, OTA in sweet wines produced in south Europe from 2006 to 2010 exceeded by far the EU MAL (Espejo \& Armada, 2009; Murillo-Arbizu, Amézqueta, González-Peñas, \& de Cerain, 2010). Ratola, Abade, Simões, Venâncio, and Alves (2005) stated that OTA levels were below $2 \mu \mathrm{g} \mathrm{L}^{-1}$ in port and a Portuguese white-liqueur wine was naturally contaminated at $1.59 \mu \mathrm{g} \mathrm{L}^{-1}$ (Ratola et al., 2006).

Sweet wine had the highest percentage of samples that were positive for OTA (72\%). Mean OTA values of $4.47 \mu \mathrm{g} \mathrm{L}^{-1}$ were detected in "special" Spanish wines, with an extreme of $15.25 \mu \mathrm{g} \mathrm{L}{ }^{-1}$, where 0.97 to $7.30 \mu \mathrm{g} \mathrm{L} \mathrm{L}^{-1}$ in Spanish sweet wines were also reported (Stratakou \& van der Fels-Klerx, 2010). Other surveys indicated contaminated samples were at $51.5 \%$. Median and mean values of 466 and $833 \mathrm{ng} \mathrm{L}^{-1}$ were obtained for a set of six wines and such levels were similar to values previously reported for sweet wines (Burdaspal \& Legarda, 2007). 


\subsection{Ochratoxin A reduction by vineyard management}

\subsubsection{General}

The occurrence of OTA in wine may be decreased by ca. $80 \%$ using effective vineyard management (Gambuti et al., 2005) and considerable control can be achieved by reducing damage to grapes (Cozzi, Pascale, Perrone, Visconti, \& Logrieco, 2006). Efficient bunch aeration is useful for controlling fungal infection which is achieved by optimizing cultivation systems, resulting in lower temperatures and relative humidity microclimates in the vineyard. Also, A. carbonarius will infect the berries more readily if they are grown close to the soil and the risk of OTA in grapes can be minimised by careful visual inspection to avoid damaged and discoloured berries (Visconti, Perrone, Cozzi, \& Solfrizzo, 2008). Reducing berry drop and discarding rotten bunches away from the vines may reduce the incidence of $A$. carbonarius in vineyard soil (Hocking et al., 2007). Finally, pressing of grapes and clarification steps can also remove a significant proportion of OTA during vinification (Hocking et al., 2007). Grapes require being stored for $<8 \mathrm{~h}$ in part because it prevents ochratoxigenic penicillia growing in stored grapes (Blesa et al., 2006).

\subsubsection{Fungicides/insecticides}

The highest OTA levels occur in vineyards where pest and disease control is insufficient and, for example, the greatest Aspergillus levels are observed where the moth Lobesia was uncontrolled (Varga \& Kozakiewicz, 2006). The OTA reducing effects of fungicides depend on the type/specificity and timing of application: Cyprodinil and Cyprodinil/Fludioxonil are the most effective compounds for $A$. carbonarius and OTA reduction (Medina et al., 2007; Medina, Mateo, Valle-Algarra, Mateo, \& J. M., 2007; Stratakou \& van der Fels-Klerx, 2010). Combinations of Euparen (a sulphamide) and Mycodifol, or Captan were found effective against black aspergilli colonising grapes. Azoxystrobin (a strobilurin derivative) or Dinocap (a dinitrophenyl derivative), in combination with sulphur, effectively decreased OTA in wines. The fungicides Switch, Scala (containing the pyrimidine fungicide pyrimethanil) and Mikal (containing fosetyl-Al and the dicarboximide folpel) were found the most effective for reducing fungal colonization and OTA content (Battilani, Giorni, \& Pietri, 2003). Furthermore, Lufox (a carbamate insecticide containing luferunon and fenoxycarb), Decis (a pyrethroid insecticide containing delthametrin) and Bacillus thuringiensis (Bt) were successful in lowering OTA content of wines (Bae, Fleet, \& Heard, 2004; Battilani et al., 2003). The use of fungicides must be considered carefully because some (e.g. carbendazim) reduce fungi but stimulate OTA production (Amézqueta et al., 2009). Finally, the use of pesticides in the vineyard may result in mutation of the fungal population (Paterson \& Lima, 2015) as some pesticides are mutagenic. The fungi may be unrepresentative of the wild type fungi and which requires consideration by researchers in the field.

\subsection{Post-harvest factors affecting ochratoxin A}

Rapid transport to the winery, cool storage of harvested grapes and sanitary wineries minimize the potential for postharvest OTA contamination (Visconti et al., 2008). Mechanical harvesting may permit a high amount of rotten bunches into the wine-making process, increasing OTA contamination. Delayed harvest increases the risk of OTA contamination (Bellí et al., 2004; Bellí et al., 2007; Gambuti et al., 2005).

\subsection{Methods for reducing ochratoxin $A$}

Yeast strains that display enhanced binding of OTA may be used for fermentation or added as dead cells (La Penna, Nesci, \& Etcheverry, 2004; Petruzzi et al., 2014) where yeast hulls added to Shiraz wine yielded a 43\% reduction in OTA by binding (Leong et al., 2006a; Leong et al., 2006b). However, the potential of OTA being added to wine by the addition of contaminated yeast must be avoided (Gottschalk, Biermaier, Gross, Schwaiger, \& Gareis, 2016). Epiphytic yeast were used successfully in vitro to inhibit $A$. carbonarius and $A$. niger on wounded grapes (Bleve, Grieco, Cozzi, Logrieco, \& Visconti, 2006). Furthermore, the addition of bacteria and adsorbents can reduce the OTA content of wine (Varga \& Kozakiewicz, 2006) and OTA biodegradation by a Pediococcus parvulus strain is a potential treatment (Abrunhosa et al., 2014).

Bentonite decreased OTA by $67 \%$ (Stratakou \& van der Fels-Klerx, 2010). Wine fining agents such as potassium caseinate or activated carbon have shown reductions of $82 \%$ but may damage wine quality (Abrunhosa, Santos, \& Venâncio, 2006). Some (a) bacteria and (b) fungi are able to degrade OTA in vitro by $>95 \%$ where some also demonstrated detoxifying properties in vivo (Fuchs et al., 2008). Carboxypeptidase A degrades OTA and the use of atoxigenic $A$. niger strains as sources of the enzyme has been suggested; a carboxypeptidase present in Phaffia rhodozyma can degrade OTA by $90 \%$. Other A. niger enzymes can degrade OTA efficiently such as a crude lipase preparation, and a metalloenzyme (Abrunhosa et al., 2006; Abrunhosa \& Venâncio, 2007).

\subsubsection{Reduction of ochratoxin A during vinification}

Grape washing, fermentation and pressing can reduce OTA levels: reduction of OTA concentration amounted to $47-52 \%$ and $53-70 \%$ during red and white grape must fermentation respectively (Amézqueta et al., 2009), in part because OTA binds to grape proteins and yeast cell walls during fermentation (Bejaoui, Mathieu, Taillandier, \& Lebrihi, 2004). Also, a decrease of $17 \%$ in OTA was observed in bottles of 'Negroamaro' wine after 12 months of storage (Grazioli, Fumi, \& Silva, 2006) which may be explained by OTA being dissociated partially at the normal $\mathrm{pH}$ of wine causing the compound to have a negative $\mathrm{pH}$ and allowing it to combine with positively charged surfaces, hence reducing the free concentration in the stored wine (Anli \& Bayram, 2009). Solid-liquid separations after pressing and fermentation are responsible for removal of OTA (Cecchini, Morassut, Garcia Moruno, \& Di Stefano, 2006) from the metabolism of lactic acid bacteria (the malolactate fermentation) (Fernandes et al., 2007) and/or adsorption onto bacterial cell walls.

\subsection{Growth and ochratoxin A production in vitro}

Growth of $A$. carbonarius is favoured by high $\mathrm{a}_{\mathrm{w}}$ (e.g. 0.98) and temperatures, whilst OTA production is increased at temperate temperature (ca. $20{ }^{\circ} \mathrm{C}$ ) and $0.96-0.98 \mathrm{a}_{\mathrm{w}}$ (Hocking et al., 2007; Medina et al., 2007; Medina et al., 2007). A. carbonarius and A. niger grew optimally at 30 and $35{ }^{\circ} \mathrm{C}$ respectively, whereas optimum $\mathrm{a}_{\mathrm{w}}$ for growth was 0.97-0.99 for both species (Anli \& Bayram, 2009; Paterson \& Lima, 2011). The optimum water activity quoted for toxin production was between 0.95 and 0.995 . Warmer, followed by cooler temperatures will encourage high initial growth and OTA levels. Most $A$. carbonarius strains do not grow below $15{ }^{\circ} \mathrm{C}$ and the optimum $\mathrm{a}_{\mathrm{w}}$ for growth varies from 0.930 to 0.987 , with the widest $\mathrm{a}_{\mathrm{w}}$ tolerance at $25-30{ }^{\circ} \mathrm{C}$. A great deal of strain variation has been demonstrated by Garcia, Ramos, Sanchis, and Marín (2011) who employed $25^{\circ} \mathrm{C}$ as the generalised optimal growth temperature. A. carbonarius strains produced the highest OTA levels at 15 and $20{ }^{\circ} \mathrm{C}$ compared to $20-25{ }^{\circ} \mathrm{C}$ for $A$. nigeraggregate strains. Maximum OTA production was at (a) 5 and (b) 7-13 days for (a) A. carbonarius and (b) A. niger respectively (Battilani, Magan, \& Logrieco, 2006).

The survival of $A$. carbonarius conidia and subsequent growth was prolonged at low temperatures and $\mathrm{a}_{\mathrm{w}}$ below 0.6 (Leong et al., 2006a; Leong et al., 2006b). Two Greek A. carbonarius isolates grew optimally at $30-35{ }^{\circ} \mathrm{C}$ and $0.96 \mathrm{a}_{\mathrm{w}}$, although maximum OTA production occurred under suboptimal growth conditions $\left(15-20{ }^{\circ} \mathrm{C}\right.$ and $\left.0.93-0.96 \mathrm{a}_{\mathrm{w}}\right)$. Growth was observed exclusively at $0.85 \mathrm{a}_{\mathrm{w}}$ and $25^{\circ} \mathrm{C}$ where the fungus failed to grow at other temperatures at this $\mathrm{a}_{\mathrm{w}}$. Maximum OTA production was detected after 25 days of incubation at $20{ }^{\circ} \mathrm{C}$ and $0.96 \mathrm{a}_{\mathrm{w}}$. 


\section{Aflatoxins and aflatoxigenic fungi}

Aflatoxins (AF) are the most important mycotoxins with AFB1 being the highest carcinogenic natural compound known. They caused the toxicity of animals feeds containing contaminated peanut meal leading to the death of 100,000 turkeys from acute liver necrosis and are structurally related difuranocoumarins. The mycotoxins exhibit hepatocarcinogenicity and hepatotoxicity: acute aflatoxicosis occurs when moderate to high levels are consumed. The disease symptoms may include haemorrhage, acute liver damage, oedema, alternation of digestion, absorption and/or metabolism of nutrients and may result in death, often attributable in tropical and subtropical regions of the world. The IARC has classified AF as group I carcinogens.

Over 100 countries restrict the content of $\mathrm{AF}$ in food and feed (Varga et al., 2015), although wine does not have regulations relating to AF. These mycotoxins are produced predominantly by A. flavus and Aspergillus parasiticus (Paterson et al., 2014; Paterson \& Lima, 2010a; Paterson \& Lima, 2010b). The presence of AF in wine has not been studied systematically. Interestingly, AFB2 was reported in $87.5 \%$ of Spanish wine samples and a Valdepeñas wine contained as much as $25.73 \mu \mathrm{g} \mathrm{L}^{-1}$ AFB2, where many other samples were of similar values (Pérez-Ortega, Gilbert-López, García-Reyes, Ramos-Martos, \& MolinaDiaz, 2012). This concentration is too high to be reasonable and the current authors assume it is a misprint. Nine (30\%) sweet Sicilian wines contained at least one with quantifiable AF with concentrations up to $0.068 \mu \mathrm{g} \mathrm{L}^{-1}$ and $13 \%$ contained quantifiable AFB1 (Di Stefano et al., 2015). AFB1 contamination of musts was reported, with $40 \%$ of samples containing $\mathrm{AF}$ in a range from $0.01-0.46 \mu \mathrm{g} \mathrm{L}^{-1}$ (El Khoury, Rizk, Lteif, Azouri, \& Delia, 2009). Serra, Braga, and Venâncio (2005) stated that AF had not been reported in wine, and Stratakou and van der FelsKlerx (2010) erroneously cite Serra et al. (2005) as stating that AF in "grapes" was demonstrated as "low" whereas there are no data on this topic in Serra et al. (2005). However, A. flavus represented the third most frequent fungus isolated from grapes (Serra et al., 2005) and $A$. parasiticus has been isolated from grapes (Rousseaux et al., 2014). Overall, more work is required on AF contamination of wine.

\section{Patulin and producing fungi}

Patulin (PAT) is a water soluble lactone produced via the polyketide metabolic pathway by many species of fungi (e.g. those within Penicillium, Aspergillus and Byssochlamys). The mycotoxin is most often associated with Penicillium expansum and is found frequently in apple products. It was tested unsuccessfully as a cure for the common cold and was found too toxic to humans and animals. PAT mainly induces gastrointestinal disorders including ulceration, distension and bleeding. The compound provokes congestion and oedema of pulmonary, hepatic and gastrointestinal blood vessels and tissues. Subcutaneous injection of PAT produced local sarcomas in rats and is classified in group 3 as not classifiable as to its carcinogenicity to human by IARC (Varga et al., 2015).

PAT can be found in moldy grapes at the maturation stages. Penicillium spp. do not infect the berries before harvest (Serra et al., 2005 ) and the producing fungi might be from other genera. However, $P$. expansum can be present in stored grapes (Snowdon, 1990) and PAT could be produced: $P$. expansum is found frequently in botrytized grapes (Morales-Valle, Silva, Paterson, Venâncio, \& Lima, 2011). PAT is present in grapes, grape juice and grape must (Bragulat, Abarca, \& Cabañes, 2008), although the occurrence in wine is low because it is well-known to be degraded partially by the fermentation process (Moss \& Long, 2002). The mycotoxin was detected in a rapid fermentation wine produced in Germany (Majerus, Hain, \& Kölb, 2008) where it was reduced from $157 \mu \mathrm{g} \mathrm{L}^{-1}$ to $55.5 \mu \mathrm{g} \mathrm{L}{ }^{-1}$ in 4 days. As part of the experimental procedure, $37 \mu \mathrm{g} \mathrm{L}^{-1}$ of pure patulin was added before fermentation to ensure that the compound was present. Díaz, Yañez, and Latorre (2011) state that the average reductions in fermented must were 67.3 to $83.3 \%$.

\section{Alternaria toxins and fungi}

Alternaria spp. are ubiquitous plant pathogens that may invade fruit (Asam, Konitzer, \& Rychlik, 2010) and were the most frequent fungi from grapes from Uruguay (Garmendia \& Vero, 2016). Alternaria alternata has been found as the dominant fungus on grapes in Argentina and many strains produced mycotoxins in vitro (Prendes, Merín, Andreoni, Ramirez, \& Morata de Ambrosini, 2015). Alternaria produce the phytotoxin tentoxin and the mycotoxins alternariol $(\mathrm{AOH})$, alternariol methyl ether (AME), altenuene and tenuazonic acid. AOH and AME were (a) mutagenic and clastogenic in in vitro systems and (b) carcinogenic to rats fed contaminated feed (Pavón, González, \& Martín, 2015; Prendes et al., 2015). There is no evidence of uptake from feeds into animals of Alternaria mycotoxins which questions whether they are true mycotoxins, although they are frequently referred to as such in the scientific literature.

Stable isotope dilution assays indicated $\mathrm{AOH}$ and $\mathrm{AME}$ in wine at high levels (Asam, Konitzer, Schieberle, \& Rychlik, 2009). Furthermore, the capability of $B$. cinerea to produce $\mathrm{AOH}$ prompted a study on these compounds in wine (Asam et al., 2010) as this fungus is crucial to noble rots and grape diseases. $\mathrm{AOH}$ and AME were detected in four of six samples (AOH: $1.2-4.9 \mu \mathrm{g} \mathrm{kg}^{-1}$; AME: $0.13-0.25 \mu \mathrm{g} \mathrm{kg}^{-1}$ ) (Asam et al., 2009). The "special wines" contained AOH (4/6 samples; 1.2-4.9 $\mu \mathrm{g} \mathrm{kg}^{-1}$ ) and AME (4/6 samples; $0.1-0.3 \mu \mathrm{g} \mathrm{kg}{ }^{-1}$ ), but the values did not exceed those in wines in general (Asam et al., 2010). In addition, AME was significant particularly in grape juice and red wines. Red grape juice and wine contained significant amounts of $\mathrm{AOH}$ : Whereas red grape juice was contaminated with a maximum of $1 \mu \mathrm{g}$ $\mathrm{kg}^{-1}$, values ranged up to a maximum of $7.5 \mu \mathrm{g} \mathrm{kg}{ }^{-1}$ in red wine, although median values were much lower. The maximum value of $\mathrm{AOH}$ in a white Riesling was $7.6 \mu \mathrm{gg}^{-1}$, thus exceeding the maximum value of red wine. White wine contained lower median values of $\mathrm{AOH}$ $\left(1.1 \mu \mathrm{g} \mathrm{kg}^{-1}\right)$ than red wine $\left(4.5 \mu \mathrm{g} \mathrm{kg}^{-1}\right)$.

\section{Fumonisins and fungi}

Fumonisins (FUM) are nonaketide derived mycotoxins which can be classified into four groups structurally. They are similar to sphinganine and disrupt the biosynthesis of sphingolipids by inhibition of ceramide synthase. Ingestion is associated with several fatal diseases of animals. They are the possible aetiological agents of oesophageal cancer in several countries such as China and South Africa (Marasas, 2001). Fumonisin $\mathrm{B} 1$ is considered as possibly carcinogenic to humans (group 2B) by IARC. A. niger was considered to the fungus responsible for production of FUM in wine (Logrieco et al., 2009). However, Mikusová et al. (2010) isolated FUM-producing fusaria from grapes. The first reported natural occurrences of FUMB2 in the grape-wine chain, at levels of 0.01 and $0.4 \mu \mathrm{g} \mathrm{L}^{-1}$, were in two samples of must (Logrieco, Ferracane, Visconti, \& Ritieni, 2010). Thirty-one strains belonging to four Aspergillus species isolated from grape were evaluated for FUMB2 in vitro: Four of eight $A$. niger strains produced detectable FUMB2 (29-293 $\mathrm{mg} \mathrm{g}^{-1}$ ). Mogensen, Frisvad, \& Thrane (2010) demonstrated that $A$. niger isolated from raisins produced FUMB2 and FUMB4 when cultured on grapes or raisins. Mogensen, Larsen, \& Nielsen (2010) demonstrated the frequent occurrence of these mycotoxins in wine but in low concentrations.

Fusarium verticillioides has been detected from rotting grapes (Lorenzini \& Zapparoli, 2015) and is a well-known fumonisin producer. Several other species of Fusarium can produce fumonisins, e.g. F. oxysporum produces only the C-series. A. niger and A. welwitschiae is considered to produce mainly FUM B2 and B4. Some Tolypocladium species may produce FUM $\mathrm{B} 1$ and $\mathrm{B} 4$. 


\section{Mycotoxins detected in wine by development of multi- mycotoxin methods}

There have been various method development papers often using spiked samples. Some interesting results from these types of papers include reports of potential mycotoxins such as mycophenolic acid in "moldy" wine (Sulyok, Krska, \& Schuhmacher, 2007); Tamura, Takahashi, Uyama, and Mochizuki (2012) analysed for patulin, deoxynivalenol, aflatoxins B1, B2, G1, G2, M1, T-2 toxin, HT-2 toxin, zearalenone, fumonisins B1, B2, B3, and ochratoxin A and detected only FUM and OTA in some samples. Al-Taher et al. (2013) found T-2 toxin in many samples of wine, which is interesting and requires further study.

\section{Climate change, wine, mycotoxins and models}

\subsection{General}

The influence of climate change on the production of wine may be profound (van Leeuwen and Darriet, 2016). Correspondingly, the production of mycotoxins on grapes will be highly effected. Will it be possible to produce wine (or the same wine) in (a) southern Europe and (b) parts of Australia and USA, as temperatures become increasingly high? High temperature will make growing the crop impossible in some areas and the mycotoxin issue will become irrelevant (Paterson \& Lima, 2012; Paterson, et al., 2013, 2014, 2015). This scenario is likely to occur in large areas of land normally suitable for grape production (Paterson \& Lima, 2011b). There will be an intermediate region where growing grapes is possible, but subjected to greater stress from suboptimal climatic conditions, poor soil, insects, and pest and disease microorganisms, making the process less profitable or unprofitable. Here, mycotoxins will become a particularly serious problem as the toxigenic fungi will be able to invade the crop more readily. Modelling studies (see later) require to consider the effect of climate change on crops as a priority, in addition to the effect on mycotoxin contamination.

García-Cela et al. (2015) concluded that climate change could promote better adapted species such as $A$. niger in the south of Spain and that climate change may see an increase of FUM in grapes with decreasing OTA. Climatic change resulting in drier and hotter climatic scenarios indicates $A$. tubingensis and A. niger may be more prevalent over $A$. carbonarius, since they are better adapted to extreme high temperature and drier conditions (Garcia-Cela et al., 2014). More dangerous mycotoxins will probably become prevalent at higher temperatures and, for example, AF will tend to supersede OTA as the major mycotoxin, because temperatures will become more suitable for the thermotolerant aspergilli that produce AF (Paterson \& Lima, 2010a; Paterson \& Lima, 2017). Temperature and rainfall projections indicate that black aspergilli on grapes grown in the alpine region of Italy will probably increase in the future (Storari et al., 2012; Storari et al., 2012).

Another scenario is that grapes will be grown in new land resulting in low levels of mycotoxins because of the "Parasites Lost phenomenon", where new growth crops often have fewer pests and diseases (Paterson \& Lima, 2010a, Paterson \& Lima, 2010b; Paterson et al., 2014; Paterson \& Lima, 2015). However, an opposing factor may be a reduction of natural competing organisms which act as a form of biological control against the toxigenic fungi. The production of wine may become optimal in regions located towards the Poles as part of the general "movement of crops to the Poles" (Paterson \& Lima, 2010a, Paterson \& Lima, 2010b; Paterson, Kumar, Shabani, \& Lima, 2017; Pritchard, 2011). Overall, it is necessary to consider how climate change will impact on viniculture as this will in turn affect mycotoxin contamination.

\subsection{Climate change and viniculture}

Wine grapes are symbolic of a wide variety of crops where geographic shifts in response to climate change will occur (Paterson et al., 2017; Paterson \& Lima, 2017). Investment in new varieties with similar flavors but with changed climate tolerances may be important (van Leeuwen \& Darriet, 2016). Hannah et al. (2013) predicted that the area suitable for viticulture will decrease from between 19 and $73 \%$ in major wine producing regions by 2050 . Climate change may cause establishment of vineyards at higher elevations and latitudes in areas such as western North America. An increase in disease and potential mycotoxin contamination can be expected as the climate becomes less suitable for vines (Paterson \& Lima, 2010a; Paterson \& Lima, 2011).

Most of the world's highest quality wine-producing regions experienced warming trends from 1950 to 1999 (Jones, White, Cooper, \& Storchmann, 2005) which had a significant role in quality variations. Global wine producing regions predict an average warming of $2{ }^{\circ} \mathrm{C}$ in the next 50 years making high quality wine more difficult in high quality regions (van Leeuwen \& Darriet, 2016). In other, currently less suitable regions, more optimal climatic regimes for the production of varietals may occur. Spatial modelling research has indicated potential geographical shifts and/or expansion of vinicultural regions, with parts of southern Europe becoming too hot to produce high-quality wines and northern regions becoming viable once again (Jones et al., 2005).

Climate change impacts are likely region-specific. Modifications in cool climate regions (i.e., the Mosel Valley, Alsace, Champagne, and the Rhine Valley) to warmer climates, could lead to more consistent vintage quality and possibly ripening of warmer climate varieties. Regions, with warmer growing seasons currently (i.e., southern California, southern Portugal, the Barossa Valley, and the Hunter Valley) may become too warm for the existing varieties and hot climate maturity regions may become overly hot to produce high-quality wines: Mycotoxins will likely be affected (Paterson \& Lima, 2011). Winter temperature changes would also affect viticulture by making regions that experience hard winter freezes (e.g., the Mosel Valley, Alsace, and Washington) less prone to vine damage, while other regions (e.g., California and Australia) would have such mild winters that latent bud hardening may not be achieved and cold-limited pests may increase in number or severity. Mycotoxigenic fungi could also survive these warmer temperatures to a greater extent than occurs currently throughout the production system for wine and will tend to lead to higher, and more dangerous mycotoxin concentrations (Paterson \& Lima, 2017). It may be possible the AF could begin to increase in wine under climate change.

White, Diffenbaugh, Pal, and Giorgi (2006) estimate that potential premium wine grape production area in the conterminous United States may decline by $81 \%$ by the late 21 st century and increases in heat accumulation will cause a move to warmer climate varieties and/or lower-quality wines. Frost constraints will be reduced, and increases in the frequency of extremely hot days $\left(>35^{\circ} \mathrm{C}\right)$ in the growing season may eliminate wine grape production in many areas. Furthermore, projected climate changes shift premium wine grape production to high humidity/precipitation regions of the Pacific Northwest and New England. High humidity is associated with higher risk of quality-reducing factors such as various forms of rot and powdery mildew, and higher frequency of raindrop impacts on leaves increasing fungal dispersal. This is likely to have an increased risk from growth of mycotoxigenic fungi and mycotoxin production. Potentially, wine regions within the Mediterranean basin today (e.g. Provence, the Languedoc, Côtes Rhône Méridionales) will change the most over time: Moriondo et al. (2013) report that increases of climate change in Europe would result in new areas on the northern fringes becoming viable, changes in varietal suitability in existing regions, and southern regions becoming too hot to produce high-quality wines.

Climate change may challenge the Portuguese wine-making sector, with the requirement for adaptation/mitigation strategies to ensure its 
future sustainability (Fraga et al., 2015). Jones et al. (2005) considers that southern Portugal may become too hot for existing varieties to grow: Hannah et al. (2013) mention the predicted dramatic decrease by 2050 in suitable areas in the Iberian Peninsula and changes due to elevated $\mathrm{CO}_{2}$ may further enhance this effect. The model suggested a decrease in suitable areas within some regions, although the majority of the present vineyards remained apt until 2050. The Tóth and Végvári (2015) predictions show a lower degree of area contraction than that of Hannah et al. (2013), where a decrease in area suitable for viticulture of 25 to $73 \%$ in major wine-producing regions was predicted by 2050 . This value for the most important European vine-producing countries amounted to $2-48 \%$ in Tóth and Végvári (2015) (Moriondo et al., 2013).

Fraga et al. (2015) also project that climate change may significantly increase wine yield in the Douro Valley, Portugal, together with predicted increases under future climate conditions in Italy. However, larger grape yields are generally associated with higher economic risk and poorer wine quality. Possible adaption procedures include: (a) increasing the altitude of vineyards, (b) growing varieties more suited to future climate conditions, (c) adequate irrigation and (d) employing new agricultural practices (Santos, Malheiro, Karremann, \& Pinto, 2011).

\subsection{Modelling climate change and mycotoxin contamination}

How are climate change effects on mycotoxins determined? This can be by experienced scientists (a) interpreting existing data (Medina, Akbar, Baazeem, Rodriguez, \& Magan, 2017; Paterson et al., 2014; Paterson \& Lima, 2010a; Paterson \& Lima, 2010b; Paterson \& Lima, 2011; Paterson \& Lima, 2017) and/or (b) constructing models. A good knowledge of (a) fungal and crop physiology, (b) fungal and crop genetics and (c) what is predicted for climate change, can permit wellformed assessments.

Weather data are the main inputs in all modelling approaches, supported by cropping data (Battilani, 2016). Indeed, efforts to model the risk of mycotoxin contamination in crops are limited, perhaps relating to concerns regarding the modelling science. Empirical and mechanistic models are used to predict mycotoxin contamination in crops and are often linked and used to combine risk indices with contamination in the field (Battilani, 2016). The results of model analysis must always be interpreted carefully as plausible futures; they should not be considered precise predictions of the future (Liu \& Battilani, 2016). Similarly, the more narrative-led papers are also describing plausible futures and are not precise predictions of the future. Each approach has merits.

A priority is to develop accurate models for the effect of climate change on (a) the ability to grow vines (Jones et al., 2005) and (b) mycotoxins in wine. A major effect of climate change will be on the host without considering pathogens as a healthy crop will be less susceptible to disease than one that is stressed because of climate change. There is no point in modelling mycotoxin contamination at high temperatures if the crop would not survive these temperatures (Paterson \& Lima, 2011).

\subsubsection{Non-wine systems}

Modelling papers regarding mycotoxin contamination of crops in relation to climate change are but few. Battilani et al. (2016) undertook modelling studies of AF on maize and wheat in Europe and very high increases in $\mathrm{AF}$ was predicted in maize at $2^{\circ} \mathrm{C}$ after 100 years. Changes at $5^{\circ} \mathrm{C}$ indicated that $\mathrm{AF}$ in some areas began to decrease, particularly in the Iberian Peninsula, which may relate to the conditions being too severe even for aflatoxigenic fungi. Paterson \& Lima, 2010a; Paterson \& Lima, 2010b predicted this phenomenon and suggested that thermophilic fungi may succeed (Paterson \& Lima, 2017).

The AF in maize data can be compared to that for the effect of climate change on the ability to grow maize, which may have relevance to mycotoxins in wine and ability to grow vines. Shaw and Osborne
(2011) indicated how the ability to grow maize would change in 2050 and the data for Europe was considered further by Paterson and Lima (2012). It appeared that large parts of Europe would not be able to grow maize in regions indicted to have high risk of $\mathrm{AF}$ after 100 years by Battilani et al. (2016), perhaps relating to the different models employed. Ramirez-cabral, Kumar, and Shabani (2017) indicate that the most obvious change in Europe was an increase from mere suitability to optimal growth in large areas, including England, France, Germany, Denmark, the Netherlands, Poland, Slovakia and the Czech Republic. The model did not taken into account the high risk of AF contamination which would be detrimental to the economic and safe production of the crop (Battilani et al., 2016).

The only country with a decrease was Spain after 100 years using the MIROC analysis and this was from (a) areas where large populations of maize can persist to (b) marginal conditions for growth (Ramirezcabral et al., 2017). Knox, Daccache, Hess, and Haro (2016) indicated a very high decrease in yield of maize up to the 2080's in southern Europe (including Spain) in a Meta study of climate change effects. The large decreases in general would tend to discourage farmers producing maize in these regions, to the extent that they would cease, meaning AF would be irrelevant. Equivalent data for mycotoxins in grapes are required. In general, data on the effect of climate change on growth of vines and grapes are required when considering mycotoxin contamination of the crop.

Temperatures were projected as too high in Spain $\left(18.2-38.2{ }^{\circ} \mathrm{C}\right)$ for Alternaria spp. to grow using models, relevant to mycotoxins produced by these fungi on tomatoes. The temperatures become closer to the optimal temperature $\left(14.2-28.4^{\circ} \mathrm{C}\right)$ in Poland for Alternaria spp. Hence, the situation in Poland in $2081-2100$ is projected to be similar to the situation in Spain in 1981-2000 (Perre, Jacxsens, Liu, Devlieghere, \& Meulenaer, 2015). It is possible that equivalent situations will occur for the mycotoxins in wine scenario.

Contamination of winter wheat with DON was modelled to increase in most of north west Europe (van der Fels-Klerx, Asselt, Madsen, \& Olesen, 2013; van der Fels-Klerx, Olesen, Madsen, \& Goedhart, 2012). Even more severe impacts were predicted for spring wheat. However, variations between runs and between regions were large, and in some grids, even a decrease in DON was predicted. A similar study for the Netherlands also predicted high spatial and annual variability of DON contamination in wheat with future climate, and again the wine/mycotoxins system can be compared.

\subsubsection{Wine system}

Even fewer models relate to mycotoxins in wine with Battilani and Marco (2015) being an exception, in this case for OTA and using the "mechanistic" approach. The importance of grape variety needs further consideration in this model as it will affect OTA contamination of grapes. One fungal taxon should only be considered normally as there appeared two in the report with different optimal growth temperatures (Battilani \& Marco, 2015), although the authors adjusted for this factor. OTA producing black aspergilli have different optimal growth temperatures (see above and Garcia-Cela et al., 2014). Importantly, the model needs validation by real observations, especially of OTA contamination in the field. Two main research gaps in mycotoxin modelling studies have been identified related to the (a) (limited) number of existing quantitative models taking into account climate change and (b) validation being in limited (Liu \& Battilani, 2016). Encouragingly, the output index of the Battilani and Marco (2015) model (i.e. OTA-grapes predictions/output), showed relevant differences between low (i.e. Emilai Romagna) and high (i.e. Apulia) risk OTA areas. The purpose of Ioannidis, Kogkaki, Natskoulis, Nychas, and Panagou (2015) was to develop a modelling approach to quantify the effect of temperature, water activity (aw) and sodium metabisulphite on the growth and OTA production of $A$. carbonarius in a growth medium. Optimum values for growth were from 30 to $35^{\circ} \mathrm{C}$ and $0.96 \mathrm{aw}$, while for OTA production they were $20^{\circ} \mathrm{C}$ and $0.98 \mathrm{aw}$. The temperature is high compared to that 
quoted for this species of $30^{\circ} \mathrm{C}$ (Anli \& Bayram, 2009; Paterson \& Lima, 2011).

\section{General discussion}

Perrone et al. (2017) suggest using MS and NMR for the identification of OTA from fungi not normally associated with producing the mycotoxin as a general criterion. Reports of OTA production by A. tubingensis have been questioned (Storari et al., 2012; Storari et al., 2012) and should perhaps also be subjected to these procedures before decisions are made. In the current authors' opinions, few laboratories which require to determine the OTA capabilities of isolated fungi could afford this equipment and the technical support required. In addition, the methods can be questioned, even for strains from recognized producing species. The high majority of the papers reviewed herein do not employ MS or NMR for OTA analysis and some strains do not appear to produce the expected mycotoxin. Does this represent a false negative due to the analytical equipment? Can false positives arise from some strains within recognized producer species? An objective approach is required whereby the results of various levels of analytical sophistication (e.g. TLC, HPLC, multi-mycotoxin analysis, MS, NMR) should be compared for accuracy. A cost/benefit analysis could then be undertaken to determine the most suitable method for the standard laboratory. There is a difference between what is (a) feasible and (b) practical. This implies that laboratories without the most expensive equipment could contribute in this field of work within the limitations of the equipment employed.

An equivalent situation arises with fungal identifications. Few laboratories have the taxonomic knowledge or facilities to undertake identifications required by some expert fungal taxonomists. There may be a requirement for a second level identification at a level below the species. This has been discussed more generally by some of the current authors (Paterson, Venâncio, \& Lima, 2004) (Paterson, Venâncio, \& Lima., 2006) where a more fundamental structure of the conidiophores is recommended to be described, enabling a nonspecific identification, such as sub-genus Penicillium within the penicillia. Hence, a level of identification would be obtained less likely to be incorrect, thereby reducing confusion between, for example, species and mycotoxin production. Full identifications could be undertaken by expert laboratories at a later date. These points would enable laboratories with less (a) sophisticated equipment and/or (b) high level taxonomic expertise to participate in a satisfactory manner.

A discussion of the issues surrounding isolating fungi from coffee are presented in (Paterson et al., 2014) which apply to the current review on wine and can be referred to. Isolation methods may not give an accurate representation of the most important mycotoxigenic fungi in the wine related substrates. Some fungi are highly sporing, biasing the results of the isolation methods and endophytic fungi may not be isolated efficiently (if they exist in the wine system). Also, mutagens could alter the fungi that are isolated so that morphological or mycotoxin changes occur (Paterson \& Lima, 2015) and, for example, this could occur through the application of pesticides in vineyards.

\section{Conclusions}

There has been considerable success in decreasing OTA in wine since EU regulations were introduced. Southern Europe produced wine with the highest levels of OTA and red wines generally have most OTA. However, threats on the horizon include other mycotoxins and climate change. Many studies report factors influencing the presence of OTA in wine, but there is little concerning AF, PAT, AOH, AME and FUM and this situation requires addressing. More research on $\mathrm{AF}$ in wine requires undertaking as this is the ultimate carcinogenic natural compound and is considered generally the most dangerous mycotoxin. It is possible the other mycotoxins will become more frequent as climate change progresses. Better correlations between mycotoxigenic fungi isolated from vineyards and the occurrence of mycotoxins in must are required. Practical (a) identification schemes for the fungi and (b) analytical methods for mycotoxins from the fungi are required. More models are desirable for how climate change affects mycotoxins in wine, complimented with astute interpretation of existing data to enable a useful dialog. Modelling the effect of climate change on the growth of grapes is a priority. Climate change and the effect on mycotoxins in wine will become increasingly important.

\section{Acknowledgments}

This study was supported by the Portuguese Foundation for Science and Technology (FCT) under the scope of the strategic funding of the UID/BIO/04469/2013 unit, COMPETE 2020 (POCI-01-0145-FEDER006684) and the BioTecNorte operation (NORTE-01-0145-FEDER000004). These were funded by the European Regional Development Fund through the Norte2020-Programa Operacional Regional do Norte.

\section{References}

Abrunhosa, L., Inês, A., Rodrigues, A. I., Guimarães, A., Pereira, V. L., Parpot, P., Venâncio, A. (2014). Biodegradation of ochratoxin A by Pediococcus parvulus isolated from Douro wines. International Journal of Food Microbiology, 188, 45-52.

Abrunhosa, L., Santos, L., \& Venâncio, A. (2006). Degradation of ochratoxin A by proteases and by a crude enzyme of Aspergillus niger. Food Biotechnology, 20, 231-242.

Abrunhosa, L., \& Venâncio, A. (2007). Isolation and purification of an enzyme hydrolyzing ochratoxin A from Aspergillus niger. Biotechnology Letters, 29, 1909-1914.

Al-Taher, F., Banaszewski, K., Jackson, L., Zweigenbaum, J., Ryu, D., \& Cappozzo, J. (2013). Rapid Method for the determination of multiple mycotoxins in wines and beers by LC-MS/MS using a stable isotope dilution assay. Journal of Agricultural and Food Chemistry, 61, 2378-2384.

Altiokka, G., Can, N. O., Atkoșar, Z., \& Aboul-Enein, H. Y. (2009). Determination of ochratoxin A in Turkish wines. Journal of Food and Drug Analysis, 17, 467-473.

Amézqueta, S., González-Peñas, E., Murillo-Arbizu, M., \& López de Cerain, A. (2009). Ochratoxin A decontamination: A review. Food Control, 20, 326-333.

Anli, E., \& Bayram, M. (2009). Ochratoxin A in Wines. Food Reviews International, 25, 214-232.

Asam, S., Konitzer, K., \& Rychlik, M. (2010). Precise determination of the Alternaria mycotoxins alternariol and alternariol monomethyl ether in cereal, fruit and vegetable products using stable isotope dilution assays. Mycotoxin Research, 27, 23-28.

Asam, S., Konitzer, K., Schieberle, P., \& Rychlik, M. (2009). Stable isotope dilution assays of alternariol and alternariol monomethyl ether in beverages. Journal of Agriculture and Food Chemistry, 57, 5152-5160.

Bae, S., Fleet, G. H., \& Heard, G. M. (2004). Occurrence and significance of Bacillus thuringiensis on wine grapes. International Journal of Food Microbiology, 94, 301-312.

Barberis, M. G., Merlera, G., Reynoso, M. M., Chulze, S. N., \& Torres, A. M. (2014). Factors affecting distribution and abundance of Aspergillus section Nigri in vineyard soils from grapevine growing regions of Argentina. Journal of the Science of Food and Agriculture, 94, 3001-3007.

Battilani, P. (2016). Recent advances in modeling the risk of mycotoxin contamination in crops. Current Opinion in Food Science, 11, 10-15.

Battilani, P., Giorni, P., \& Pietri, A. (2001). Role of cultural factors on the content of ochratoxin A in grape. Journal of Plant Pathology, 83, 231.

Battilani, P., Giorni, P., \& Pietri, A. (2003). Epidemiology of toxin producing fungi and ochratoxin A occurrence in grape. European Journal of Plant Pathology, 109, 715-722.

Battilani, P., Magan, N., \& Logrieco, A. (2006). European research on ochratoxin A in grapes and wine. International Journal of Food Microbiology, 111, S2-4.

Battilani, P., \& Marco, C. L. (2015). OTA-Grapes: a mechanistic model to predict ochratoxin a risk in grapes, a step beyond the systems approach. Toxins, 7, 3012-3029.

Battilani, P., Toscano, P., van Der Fels-Klerx, H. J., Moretti, A., Camardo Leggieri, M., Brera, C., ... Robinson, T. (2016). Aflatoxin B 1 contamination in maize in Europe increases due to climate change. Scientific Reports, 6.(12 April).

Bejaoui, H., Mathieu, F., Taillandier, P., \& Lebrihi, A. (2004). Ochratoxin A removal in synthetic and natural grape juices by selected oenological Saccharomyces strains. Journal of Applied Microbiology, 97, 1038-1044.

Bejaoui, H., Mathieu, F., Taillandier, P., \& Lebrihi, A. (2006). Black aspergilli and ochratoxin A production in French vineyards. International Journal of Food Microbiology, 111, S46-52.

Bellí, N., Marín, S., Coronas, I., Sanchis, V., \& Ramos, A. J. (2007). Skin damage, high temperature and relative humidity as detrimental factors for Aspergillus carbonarius infection and ochratoxin A production in grapes. Food Control, 18, 1343-1349.

Bellí, N., Marın, S., Sanchis, V., \& Ramos, A. J. (2004). Influence of water activity and temperature on growth of isolates of Aspergillus section Nigri obtained from grapes. International Journal of Food Microbiology, 96, 19-27.

Bellí, N., Mitchell, D., Marín, S., Alegre, I., Ramos, A. J., Magan, N., \& Sanchis, V. (2005). Ochratoxin A-producing fungi in Spanish wine grapes and their relationship with meteorological conditions. European Journal of Plant Pathology, 113, 233-239.

Bellí, N., Ramos, A. J., Sanchis, V., \& Marín, S. (2007). Incubation time and water activity 
effects on ochratoxin A production by Aspergillus section Nigri strains isolated from grapes. Letters in Applied Microbiology, 38, 72-77.

Blesa, J., Soriano, J. M., Moltó, J. C., \& Mañes, J. (2006). Factors affecting the presence of ochratoxin A in wines. Critical Reviews in Food Science and Nutrition, 46, 473-478.

Bleve, G., Grieco, F., Cozzi, G., Logrieco, A., \& Visconti, A. (2006). Isolation of epiphytic yeasts with potential for biocontrol of Aspergillus carbonarius and A. niger on grape. International Journal of Food Microbiology, 108, 204-209.

Bragulat, M. R., Abarca, M. L., \& Cabañes, F. J. (2008). Low occurrence of patulin- and citrinin-producing species isolated from grapes. Letters in Applied Microbiology, 47, 286-289.

Burdaspal, P. A., \& Legarda, T. (2007). Occurrence of ochratoxin A in sweet wines produced in Spain and other countries. Food Additives and Contaminants, 24, 976-986.

Cabañes, F. J., Accensi, F., Bragulat, M. R., Abarca, M. L., Castellá, G., Minguez, S., \& Pons, A. (2002). What is the source of ochratoxin A in wine? International Journal of Food Microbiology, 79, 213-215.

Cecchini, F., Morassut, M., Garcia Moruno, E., \& Di Stefano, R. (2006). Influence of yeast strain on ochratoxin A content during fermentation of white and red must. Food Microbiology, 23, 411-417.

Chulze, S. N., Magnoli, C. E., \& Dalcero, A. M. (2006). Occurrence of ochratoxin A in wine and ochratoxigenic mycoflora in grapes and dried vine fruits in South America. International Journal of Food Microbiology, 111(Suppl), S5-9.

Clouvel, P., Bonvarlet, L., Martinez, A., Lagouarde, P., Dieng, I., \& Martin, P. (2008). Wine contamination by ochratoxin A in relation to vine environment. International Journal of Food Microbiology, 123, 74-80.

Comuzzo, P., Rauhut, D., Werner, M., Lagazio, C., \& Zironi, R. (2013). A survey on wines from organic viticulture from different European countries. Food Control, 34, 274-282.

Coronel, M. B., Marín, S., Cano-Sancho, G., Ramos, A. J., \& Sanchis, V. (2012). Exposure assessment to ochratoxin A in Catalonia (Spain) based on the consumption of cereals, nuts, coffee, wine, and beer. Food Additives \& Contaminants, 29, 979-993 Part A, Chemistry, Analysis, Control, Exposure \& Risk Assessment.

Cozzi, G., Pascale, M., Perrone, G., Visconti, A., \& Logrieco, A. (2006). Effect of Lobesia botrana damages on black aspergilli rot and ochratoxin A content in grapes. International Journal of Food Microbiology, 111, S88-92.

Da Rocha Rosa, C. A., Palacios, V., Combina, M., Fraga, M. E., De Oliveira Rekson, A., Magnoli, C. E., \& Dalcero, A. M. (2002). Potential ochratoxin A producers from wine grapes in Argentina and Brazil. Food Additives and Contaminants, 19, 408-414.

Dachery, B., Manfroi, V., Berleze, K. J., \& Welke, J. E. (2016). Occurrence of ochratoxin A in grapes, juices and wines and risk assessment related to this mycotoxin exposure. Ciencia Rural, 46, 176-183.

De Lucca, A., \& Walsh, T. J. (2015). Mycotoxins of Fusarium spp.: Biochemistry and Toxicology. In R. R. M. Paterson, \& N. Lima (Eds.). Molecular biology of food and water borne mycotoxigenic and mycotic fungi (pp. 323-353). Baton Rouge: CRC Press.

Di Stefano, V., Pitonzo, R., Avellone, G., Di Fiore, A., Monte, L., \& Ogorka, A. Z. T. (2015). Determination of aflatoxins and ochratoxins in Sicilian sweet wines by HighPerformance Liquid Chromatography with fluorometric detection and immunoaffinity cleanup. Food Analytical Methods, 8, 569-577.

Díaz, G. A., Torres, R., Vega, M., \& Latorre, B. A. (2009). Ochratoxigenic Aspergillus species on grapes from Chilean vineyards and Aspergillus threshold levels on grapes. International Journal of Food Microbiology, 133, 195-199.

Díaz, G. A., Yañez, L., \& Latorre, B. A. (2011). Low of patulin-producing strains of Penicillium in grapes and patulin degradation during winemaking in Chile. American Journal for Enology and Viticulture, 62, 542-546.

Diguta, C. F., Vincent, B., Guilloux-Benatier, M., Alexandre, H., \& Rousseaux, S. (2011). PCR ITS-RFLP: A useful method for identifying filamentous fungi isolates on grapes. Food Microbiology, 28, 1145-1154.

EC (1999). Council regulation (EC) No 1493/1999 of 17 May 1999. On the common organisation of the market in wine. Official Journal of the European Union, L179(1), $1-83$.

EC (2005). Council regulation (EC) No. 123/2005 of 26 January 2005 Amending regulation (EC) No. 466/2001 as regards ochratoxin A. Official Journal of the European Union, L25, 3-5.

EC (2006). Council regulation (EC) No. 1881/2006 of 19 December 2006. Setting maximum levels for certain contaminants in foodstuffs. Official Journal of the European Union, L364, 5-24.

El Khoury, A., Rizk, T., Lteif, R., Azouri, H., \& Delia, M. (2009). Fungal contamination and aflatoxin B1 and ochratoxin A in Lebanese wine-grapes and musts. Food and Chemical Toxicology, 46, 2244-2250.

Espejo, F. J., \& Armada, S. (2009). Effect of activated carbon on ochratoxin A reduction in "pedro Ximenez" sweet wine made from off-vine dried grapes. European Food Research and Technology, 229, 255-262.

van der Fels-Klerx, H. J., Asselt, E. D. V., Madsen, M. S., \& Olesen, J. E. (2013). Impact of climate change effects on contamination of cereal grains with deoxynivalenol. PLoS One, 8, 1-10.

van der Fels-Klerx, H. J., Olesen, J. E., Madsen, M. S., \& Goedhart, P. W. (2012). Climate change increases deoxynivalenol contamination of wheat in north-western Europe. Food Additives and Contaminants, 29, 1593-1604.

Fernandes, A., Ratola, N., Cerdeira, A., Alves, A., \& Venâncio, A. (2007). Changes in ochratoxin A concentration during wine making. American Journal of Enology and Viticulture, 58, 92-96.

Fernandes, P. J., Barros, N., \& Câmara, J. S. (2013). A survey of the occurrence of ochratoxin A in Madeira wines based on a modified QuEChERS extraction procedure combined with liquid chromatography-triple quadrupole tandem mass spectrometry. Food Research International, 54, 293-301.

Fraga, H., Santos, J. A., Moutinho-Pereira, J., Carlos, C., Silvestre, J., Eiras-Dias, J., ... Malheiro, A. C. (2015). Statistical modelling of grapevine phenology in Portuguese wine regions: observed trends and climate change projections. The Journal of Agricultural Science, 154, 795-811.

Freire, L., Reinis, F., Passamani, F., Betsy, A., Cássia, R. D., Resende, M., ... Roberto, L. (2017). Influence of physical and chemical characteristics of wine grapes on the incidence of Penicillium and Aspergillus fungi in grapes and ochratoxin A in wines. International Journal of Food Microbiology, 241, 181-190.

Frisvad, J. C., Larsen, T. O., De Vries, R., Meijer, M., Houbraken, J., Cabañes, F. J., ... Samson, R. A. (2007). Secondary metabolite profiling, growth profiles and other tools for species recognition and important Aspergillus mycotoxins. Studies in Mycology, 59, 31-37.

Frisvad, J. C., \& Samson, R. A. (2004). Polyphasic taxonomy of Penicillium subgenus Penicillium: A guide to identification of food and air-borne terverticillate Penicillia and their mycotoxins. Studies in Mycology, 49, 1-174.

Fuchs, S., Sontag, G., Stidl, R., Ehrlich, V., Kundi, M., \& Knasmüller, S. (2008). Detoxification of patulin and ochratoxin A, two abundant mycotoxins, by lactic acid bacteria. Food and Chemical Toxicology, 46, 1398-1407.

Gambuti, A., Strollo, D., Genovese, A., Ugliano, M., Ritieni, A., \& Moio, L. (2005) Influence of enological practices on ochratoxin A concentration in wine. American Journal of Enology and Viticulture, 56, 155-162.

Garcia, D., Ramos, A. J., Sanchis, V., \& Marín, S. (2011). Is intraspecific variability of growth and mycotoxin production dependent on environmental conditions? A study with Aspergillus carbonarius isolates. International Journal of Food Microbiology, 144, 432-439.

García-Cela, E., Crespo-Sempere, A., Gil-Serna, J., Porqueres, A., \& Marin, S. (2015). Fungal diversity, incidence and mycotoxin contamination in grapes from two agroclimatic Spanish regions with emphasis on Aspergillus species. Journal of the Science of Food and Agriculture, 95, 1716-1729.

Garcia-Cela, E., Crespo-Semprre, A., Ramos, A. J., Sanchis, V., \& Marin, S. (2014). Ecophysiological characterization of Aspergillus carbonarius, Aspergillus tubingensis and Aspergillus niger isolated from grapes in Spanish vineyards. International Journal of Food Microbiology, 173, 89-98.

Garmendia, G., \& Vero, S. (2016). Occurrence and biodiversity of Aspergillus section Nigri on "Tannat" grapes in Uruguay. International Journal of Food Microbiology, 216, 31-39.

Giovannoli, C., Passini, C., Nardo, F. D., Anfossi, L., \& Baggiani, C. (2014). Determination of ochratoxin A in Italian red wines by molecularly imprinted solid phase extraction and HPLC analysis. Journal of Agricultural and Food Chemistry, 62, 5220-5225.

Gottschalk, C., Biermaier, B., Gross, M., Schwaiger, K., \& Gareis, M. (2016). Ochratoxin A in brewer's yeast used as food supplement. Mycotoxin Research, 32, 1-5.

Grazioli, B., Fumi, M. D., \& Silva, A. (2006). The role of processing on ochratoxin A content in Italian must and wine: A study on naturally contaminated grapes. International Journal of Food Microbiology, 111, S93-96.

Guérin, L., Guyot, F.B. \& Vincent, V. L. (2007). 8th Symposium International d'œnologie. In Lonvaud, P. T. A., Gery, L., Miettn-Peuchot, M., Darriet, P., Lucas, P. \& de Revel, G. (Eds.). (pp. 76-78). Villeneuve d'Ornon: Vigne et Vin Publications Internationales.

Hannah, L., Roehrdanz, P. R., Ikegami, M., Shepard, A. V., Shaw, M. R., Tabor, G., .. Hijmans, R. J. (2013). Climate change, wine, and conservation. Proceedings of the National Academy of Sciences of the United States of America, 110, 6907-6912.

Hocking, A. D., Leong, S.-L. L., Kazi, B. A., Emmett, R. W., \& Scott, E. S. (2007). Fungi and mycotoxins in vineyards and grape products. International Journal of Food Microbiology, 119, 84-88.

Ioannidis, A., Kogkaki, E. A., Natskoulis, P. I., Nychas, G. E., \& Panagou, E. Z. (2015). Modelling the influence of temperature, water activity and sodium metabisulphite on the growth and OTA production of Aspergillus carbonarius isolated from Greek wine grapes. Food Microbiology, 49, 12-22.

Jones, G., White, M., Cooper, O., \& Storchmann, K. (2005). Climate change and global wine quality. Climatic Change, 73, 319-343.

Kizis, D., Natskoulis, P., Nychas, G. E., \& Panagou, E. Z. (2014). Biodiversity and ITS-RFLP characterisation of Aspergillus section Nigri isolates in grapes from four traditional grape-producing areas in Greece. PLoS One, 9.

Knox, J., Daccache, A., Hess, T., \& Haro, D. (2016). Meta-analysis of climate impacts and uncertainty on crop yields in Europe. Environmental Research Letters, 11, 113004.

La Penna, M., Nesci, A., \& Etcheverry, M. (2004). In vitro studies on the potential for biological control on Aspergillus section Flavi by Kluyveromyces spp. Letters in Applied Microbiology, 38, 257-264.

Labrinea, E. P., Natskoulis, P. I., Spiropoulos, A. E., Magan, N., \& Tassou, C. C. (2011). A survey of ochratoxin A occurrence in Greek wines. Food Additives and Contaminants, 4, 61-66.

van Leeuwen, C., \& Darriet, P. (2016). The impact of climate change on viticulture and wine quality. Journal of Wine Economics, 11, 150-167.

Leong, S. L., Hocking, A. D., \& Scott, E. S. (2006a). Effects of water activity and temperature on the survival of Aspergillus carbonarius spores in vitro. Letters in Applied Microbiology, 42, 326-330.

Leong, S. L., Hocking, A. D., \& Scott, E. S. (2006b). Survival and growth of Aspergillus carbonarius on wine grapes before harvest. International Journal of Food Microbiology, 111, S83-87.

Leong, S. L., Hocking, A. D., Pitt, J. I., Kazi, B. A., Emmett, R. W., \& Scott, E. S. (2006). Australian research on ochratoxigenic fungi and ochratoxin A. International Journal of Food Microbiology, 111, S10-17.

Leong, S. L., Hocking, A. D., \& Scott, E. S. (2007). Aspergillus species producing ochratoxin A: Isolation from vineyard soils and infection of Semillon bunches in Australia. Journal of Applied Microbiology, 102, 124-133.

Liu, C., \& Battilani, P. (2016). Modelling climate change impacts on mycotoxin contamination. World Mycotoxin Jornal, 9, 717-726.

Liu, Y., \& Wu, F. (2010). Global burden of aflatoxin-induced hepatocellular carcinoma: A risk assessment. Environmental Health Perspectives, 118, 818-824. 
Logrieco, A., Ferracane, R., Haidukowsky, M., Cozzi, G., Visconti, A., \& Ritieni, A. (2009). Fumonisin $\mathrm{B} 2$ production by Aspergillus niger from grapes and natural occurrence in must. Food Additives and Contaminants, 26, 1495-1500.

Logrieco, A., Ferracane, R., Visconti, A., \& Ritieni, A. (2010). Natural occurrence of fumonisin B2 in red wine from Italy. Food Additives and Contaminants, 27, 1136-1141.

Lorenzini, M., \& Zapparoli, G. (2015). Occurrence and infection of Cladosporium, Fusarium, Epicoccum and Aureobasidium in withered rotten grapes during post-harvest dehydration. Antonie Van Leeuwenhoek, 108, 1171-1180.

Lucchetta, G., Bazzo, I., Cortivo, G. D., Stringher, L., Bellotto, D., Borgo, M., \& Angelini, E. (2010). Occurrence of black aspergilli and ochratoxin a on grapes in Italy. Toxins, 2, $840-855$

Magan, N., \& Aldred, D. (2005). Conditions of formation of ochratoxin A in drying, transport and in different commodities. Food Additives and Contaminants, 22, 10-16.

Magnoli, C., Violante, M., Combina, M., Palacio, G., \& Dalcero, A. (2003). Mycoflora and ochratoxin-producing strains of Aspergillus section Nigri in wine grapes in Argentina. Letters in Applied Microbiology, 37, 179-184.

Majerus, P., Hain, J., \& Kölb, C. (2000). Occurrence of ochratoxin A in wines, fruit juices and seasonings. Archiv für Lebensmittelhygiene, 51, 95-97.

Majerus, P., Hain, J., \& Kölb, C. (2008). Patulin in grape must and new, still fermenting wine (Federweißer). Mycotoxin Research, 24, 135-139.

Marasas, W. F. O. (2001). Discovery and occurrence of the fumonisins: A historical perspective. Environal Health Perspect, 109, 239-243.

Mateo, R., Medina, Á., Mateo, E. M., Mateo, F., \& Jiménez, M. (2007). An overview of ochratoxin A in beer and wine. International Journal of Food Microbiology, 119, 79-83.

Medina, A., Akbar, A., Baazeem, A., Rodriguez, A., \& Magan, N. (2017). Climate change, food security and mycotoxins: Do we know enough? Fungal Biology Reviews, 31, 143-154.

Medina, Á., Jiménez, M., Mateo, R., \& Magan, N. (2007). Efficacy of natamycin for control of growth and ochratoxin A production by Aspergillus carbonarius strains under different environmental conditions. Journal of Applied Microbiology, 103, 2234-2239.

Medina, A., Mateo, R., Lo, L., \& Valle-algarra, F. M. (2005). Study of Spanish grape mycobiota and ochratoxin A production by isolates of Aspergillus tubingensis and other members of Aspergillus section Nigri. Applied and Environmental Microbiology, 71, 4696-4702.

Medina, Á., Mateo, R., Valle-Algarra, F. M., Mateo, E. M., \& J. M. (2007). Effect of carbendazim and physicochemical factors on the growth and ochratoxin A production of Aspergillus carbonarius isolated from grapes. International Journal of Food Microbiology, 119, 230-235.

Mikusová, P., Ritieni, A., Santini, A., Juhasová, G., \& Srobárová, A. (2010). Contamination by moulds of grape berries in Slovakia. Food Additives \& Contaminants, 27, 738-747 Part A, Chemistry, Analysis, Control, Exposure \& Risk Assessment.

Miraglia, M., \& Brera, C. (2002). Assessment of dietary intake of ochratoxin A by the population of EU member states. Reports on Tasks for Scientific Cooperation, 1-153. January https://ec.europa.eu/food/sites/food/files/safety/docs/cs_contaminants catalogue ochratoxin task 3-2-7 en.pdf, Accessed date: 7 December 2017.

Mogensen, J. M., Frisvad, J. C., \& Thrane, U. (2010). Production of fumonisins B2 and B4 by Aspergillus niger on grapes and raisins. Journal of Agricultural and Food Chemistry, 58, 954-958.

Mogensen, J. M., Larsen, T. O., \& Nielsen, K. F. (2010). Widespread occurrence of the mycotoxin fumonisin B2 in wine. Journal of Agricultural and Food Chemistry, 58, 4853-4857.

Mogensen, J. M., Møller, K. A., Von Freiesleben, P., et al. (2011). Production of fumonisins B2 and B4 in Tolypocladium species. Journal of Industrial Microbiology \& Biotechnology, 38, 1329-1335.

Moriondo, M., Jones, G. V., Bois, B., Dibari, C., Ferrise, R., Trombi, G., \& Bindi, M. (2013). Projected shifts of wine regions in response to climate change. Climate Change, 119, 825-839.

Moss, M. O., \& Long, M. T. (2002). Fate of patulin in the presence of the yeast Saccharomyces cerevisiae. Food Additives and Contaminants, 19, 387-399.

Morales-Valle, H., Silva, L. C., Paterson, R. R. M., Venâncio, A., \& Lima, N. (2011). Effects of the origins of Botrytis cinerea on earthy aromas from grape broth media further inoculated with Penicillium expansum. Food Microbiology, 28, 1048-1053.

Murillo-Arbizu, M. T., Amézqueta, S., González-Peñas, E., \& de Cerain, L. A. (2010). Occurrence of ochratoxin A in southern Spanish generous wines under the denomination of origin "Jerez-Xérès-Sherry and 'Manzanilla' Sanlúcar de Barrameda." Toxins, 2, 1054-1064.

OIV (2016a). International code of oenological practices OIV code sheet issue 2015/01, chapter I. 1.3-1. http://www.oiv.int/en/technical-standards-and-documents/ oenological-practices/international-code-of-oenological-practices, Accessed date: 15 August 2017.

OIV (2016b). World vitiviniculture situation. Wine producers. 38th World Congress of Vine and Wine. Mainzhttp://www.oiv.int/public/medias/5029/world-vitiviniculturesituation-2016.pdf, Accessed date: 15 August 2017.

Oliveri, C., Bella, P., Tessitori, M., Catara, V., \& Rosa, R. L. (2016). Grape and environmental mycoflora monitoring in old, traditionally cultivated vineyards on Mount Etna, southern Italy. Journal of the Science of Food and Agriculture, 97, 65-73.

Paterson, R. R. M., \& Lima, N. (2010a). How will climate change affect mycotoxins in food? Food Research International, 43, 1902-1914.

Paterson, R. R. M., \& Lima, N. (2010b). Toxicology of mycotoxins. EXS, 100, 31-63.

Paterson, R. R. M., \& Lima, N. (2011). Further mycotoxin effects from climate change. Food Research International, 44, 2555-2566.

Paterson, R. R. M., \& Lima, N. (2012). Climate change, fumonisins and animal feed. In E. M. Binder (Ed.). World nutrition form. NutriEconomics: Balancing global nutrition \& productivity (pp. 241-247). Leicestershire: Anytime Publishing.

Paterson, R. R. M., \& Lima, N. (2015). Mutagens affect food and water biodeteriorating fungi. Current Opinion in Food Science, 5, 8-13.

Paterson, R. R. M., \& Lima, N. (2017). Thermophilic fungi to dominate aflatoxigenic/ mycotoxigenic fungi on food under global warming. International Journal of Environmental Research and Public Health, 14, 199.

Paterson, R. R. M., Lima, N., \& Taniwaki, M. H. (2014). Coffee, mycotoxins and climate change. Food Research International, 61, 1-15.

Paterson, R. R. M., Venâncio, A., \& Lima, N. (2004). Solutions to Penicillium taxonomy crucial to mycotoxin research and health. Research in Microbiology, 155, 507-513.

Paterson, R. R. M. V., Lima, A., \& N. (2006). A practical approach for identifications based on mycotoxin characters of Penicillium. Revista Iberoamericana de Micología, 23, 155-159.

Paterson, R. R. M., Kumar, L., Shabani, F., \& Lima, N. (2017). World climate suitability projections to 2050 and 2100 for growing oil palms. The Journal of Agricultural Science, 155, 659-702.

Pavón, M. A., González, I., \& Martín, R. G. T. (2015). Alternaria spp. and mycotoxins. In R. R. M. Paterson, \& N. Lima (Eds.). Molecular biology of food and water borne mycotoxigenic and mycotic fungi (pp. 139-150). Baton Rouge: CRC Press.

Pena, A., Cerejo, F., Silva, L. J. G., \& Lino, C. M. (2010). Ochratoxin A survey in Portuguese wine by LC-FD with direct injection. Talanta, 82, 1556-1561.

Pérez-Ortega, P., Gilbert-López, B., García-Reyes, J. F., Ramos-Martos, N., \& Molina-Diaz, A. (2012). Generic sample treatment method for simultaneous determination of multiclass pesticides and mycotoxins in wines by liquid chromatography-mass spectrometry. Journal of Chromatography A, 1249, 32-40.

Perre, E. V. D., Jacxsens, L., Liu, C., Devlieghere, F., \& Meulenaer, B. D. (2015). Climate impact on Alternaria moulds and their mycotoxins in fresh produce: The case of the tomato chain. Food Research International, 68, 41-46.

Perrone, G., Logrieco, A. F., \& Frisvad, J. C. (2017). Comments on "Screening and Identification of novel ochratoxin a-producing fungi from grapes". Toxins 2016, 8, 333-In reporting ochratoxin a production from strains of Aspergillus, Penicillium and Talaromyces. Toxins, 14.

Perrone, G., Mule, G., Susca, A., Battilani, P., Pietri, A., \& Logrieco, A. (2006). Ochratoxin A production and amplified fragment length polymorphism analysis of Aspergillus carbonarius, Aspergillus tubingensis, and Aspergillus niger strains isolated from grapes in Italy. Apllied and Environmental Microbiology, 72, 680-685.

Perrone, G., Susca, A., Cozzi, G., Ehrlich, K., Varga, J., Frisvad, J. C., ... Samson, R. A. (2007). Biodiversity of Aspergillus species in some important agricultural products. Studies in Mycology, 59, 53-66.

Petruzzi, L., Sinigaglia, M., Corbo, M. R., Campaniello, D., Speranza, B., \& Bevilacqua, A. (2014). Decontamination of ochratoxin A by yeasts: Possible approaches and factors leading to toxin removal in wine. Applied Microbiology and Biotechnology, 98, 6555-6567.

Pitt, J. I. H. (1997). Fungi and food spoilage. Heildelberg: Springer.

Prelle, A., Spadaro, D., Denca, A., Garibaldi, A., \& Gullino, M. L. (2013). Comparison of clean-up methods for ochratoxin A on wine, beer, roasted coffee and chili commercialized in Italy. Toxins, 22, 1827-1844.

Prendes, L. P., Merín, M. G., Andreoni, M. A., Ramirez, M. L., \& Morata de Ambrosini, V. I (2015). Mycobiota and toxicogenic Alternaria spp. strains in Malbec wine grapes from DOC San Rafael, Mendoza, Argentina. Food Control, 57, 122-128.

Pritchard, S. G. (2011). Soil organisms and global climate change. Plant Pathology, 60 , 82-99.

Quintela, S., Villarán, M. C., Armentia, I. L. D., \& Elejalde, E. (2012). Ochratoxin A in Spanish exportation wine market. Food Control, 25(2), 501-504.

Quintela, S., Villarán, M. C., Armentia, I. L. D., \& Elejalde, E. (2011). Occurrence of ochratoxin A in Rioja Alavesa wines. Food Chemistry, 126, 302-305.

Ramirez-cabral, N. Y. Z., Kumar, L., \& Shabani, F. (2017). Global alterations in areas of suitability for maize production from climate change and using a mechanistic species distribution model (CLIMEX). Scientific Reports, 7(June), 1-13.

Ratola, N., Abade, E., Simões, T., Venâncio, A., \& Alves, A. (2005). Evolution of ochratoxin A content from must to wine in Port-wine microvinifications. Analytical and Bioanalytical Chemistry, 382, 405-411.

Ratola, N., Barros, P., Simões, T., Cerdeira, A., Venâncio, A., \& Alves, A. (2006). Worldwide interlaboratory study on the determination of ochratoxin A in different wine type samples. Chemico-Biological Interactions, 70, 720-731.

Ratola, N., Martins, L., \& Alves, A. (2004). Ochratoxin A in wines-assessing global uncertainty associated with the results. Analytica Chimica Acta, 513, 319-324.

Remiro, R., González-peñas, E., Lizarraga, E., López, A., \& Cerain, D. (2012). Quantification of ochratoxin A and five analogs in Navarra red wines. Food Control, 27, 139-145.

Remiro, R., Irigoyen, A., González-Peñas, E., Lizarraga, E., \& López de Cerain, A. (2013) Levels of ochratoxins in Mediterranean red wines. Food Control, 32(1), 63-68.

Rodrigues, P., Venâncio, A., \& Lima, N. (2009). A polyphasic approach to the identification of aflatoxigenic and non-aflatoxigenic strains of Aspergillus Section Flavi isolated from Portuguese almonds. International Journal of Food Microbiology, 129, 187-193.

Rousseaux, S., Diguta, C. F., Radoï-Matei, F., Alexandre, H., \& Guilloux-Bénatier, M. (2014). Non-Botrytis grape-rotting fungi responsible for earthy and moldy off-flavors and mycotoxins. Food Microbiology, 38, 104-121.

Ruíz Bejarano, M. J., Rodríguez, D. M. C., \& Garcia, B. C. (2010). Optimizing the process of making sweet wines to minimize the content of ochratoxin A. Journal of Agricultural and Food Chemistry, 58, 13006-13012.

Sage, L., Krivobok, S., Delbos, E., Seigle-Murandi, F., \& Creppy, E. E. (2002). Fungal flora and ochratoxin A production in grapes and musts from France. Journal of Agricultural and Food Chemistry, 50, 1306-1311.

Samson, R. A., Noonim, P., Meijer, M., Houbraken, J., Frisvad, J. C., \& Varga, J. (2007). Diagnostic tools to identify black aspergilli. Studies in Mycology, 59, 129-145.

Samson, R. A., Visagie, C. M., Houbraken, J., Hong, S.-B., Hubka, V., Klaassen, C. H. W., ... 
Kocsubé., Szigeti, G., \& Frisvad, J. C. (2014). Phylogeny, identification and nomenclature of the genus Aspergillus. Studies in Mycology, 78, 141-173.

Santos, J. A., Malheiro, A. C., Karremann, M. K., \& Pinto, J. G. (2011). Statistical modelling of grapevine yield in the Port wine region under present and future climate conditions. International Journal of Biometeorology, 55, 119-131.

Serra, R., Abrunhosa, L., Kozakiewicz, Z., \& Venâncio, A. (2003). Black Aspergillus species as ochratoxin A producers in Portuguese wine grapes. International Journal of Food Microbiology, 88, 63-68.

Serra, R., Braga, A., \& Venâncio, A. (2005). Mycotoxin-producing and other fungi isolated from grapes for wine production, with particular emphasis on ochratoxin A. Research in Microbiology, 156, 515-521.

Serra, R., Lourenço, A., Alípio, P., \& Venâncio, A. (2006). Influence of the region of origin on the mycobiota of grapes with emphasis on Aspergillus and Penicillium species. Mycological Research, 110, 971-978.

Serra, R., Mendonça, C., \& Venâncio, A. (2006). Ochratoxin A occurrence and formation in Portuguese wine grapes at various stages of maturation. International Journal of Food Microbiology, 111(Suppl), S35-9.

Shaw, M. W., \& Osborne, T. M. (2011). Geographic distribution of plant pathogens in response to climate change. Plant Pathology, 60(1), 31-43.

Siantar, D. P., Halverson, C. A., Kirmiz, C., Peterson, G. F., Hill, N. R., \& Sumer, D. (2003). Ochratoxin a in wine: Survamericaney by antibody- and polymeric-based SPE columns using HPLC/fluorescence detection. American Journal for Enology and Viticulture, 54, 170-177.

Snowdon, A. L. (1990). A colour atlas of post-harvest diseases and disorders of fruits and vegetables, general introduction and fruits. London: Wolfe Scientific.

Soleas, G. J., Yan, J., \& Goldberg, D. M. (2001). Assay of ochratoxin A in wine and beer by high-pressure liquid chromatography photodiode array and gas chromatography mass selective detection. Journal of Agriculture and Food Chemistry, 49, 2733-2740.

Soufleros, E. H., Tricard, C., \& Bouloumpasi, E. (2003). Occurrence of ochratoxin A in Greek wines. Journal of the Science of Food and Agriculture, 83, 173-179.

Spadaro, D., Lorè, A., Garibaldi, A., \& Gullino, M. L. (2010). Occurrence of ochratoxin A before bottling in DOC and DOCG wines produced in Piedmont (Northern Italy). Food Control, 21, 1294-1297.

Storari, M., Bigler, L., Gessler, C., \& Broggini, G. A. L. (2012). Assessment of the ochratoxin A production ability of Aspergillus tubingensis. Food Additives and Contaminants : Part A, 29, 1450-1454.

Storari, M., Broggini, G. A. L., Bigler, L., Cordano, E., Eccel, E., Filippi, R. D., ... Pertot, I. (2012). Risk assessment of the occurrence of black aspergilli on grapes grown in an alpine region under a climate change scenario. European Journal of Plant Pathology, 134, 631-645.

Stratakou, I., \& van der Fels-Klerx, H. J. (2010). Mycotoxins in grapes and wine in Europe: Occurrence, factors affecting the occurrence and related toxicological effects. World
Mycotoxin Journal, 3, 283-300.

Sulyok, M., Krska, R., \& Schuhmacher, R. (2007). A liquid chromatography/tandem mass spectrometric multi-mycotoxin method for the quantification of 87 analytes and its application to semi-quantitative screening of moldy food samples. Analytical and Bioanalytical Chemistry, 389, 1505-1523.

Tamura, M., Takahashi, A., Uyama, A., \& Mochizuki, N. (2012). A method for multiple mycotoxin analysis in wines by solid phase extraction and multifunctional cartridge purification, and ultra-high-performance liquid chromatography coupled to tandem mass spectrometry. Toxins, 4, 476-486.

Terra, M. F., Prado, G., Pereira, G. E., Ematné, H. J., \& Batista, L. R. (2013). Detection of ochratoxin A in tropical wine and grape juice from Brazil. Journal of the Science of Food and Agriculture, 93, 890-894.

Tóth, J. P., \& Végvári, Z. (2015). Future of winegrape growing regions in Europe. Australian Journal of Grape and Wine Research, 22, 64-72.

Valero, A., Marín, S., Ramos, A. J., \& Sanchis, V. (2008). Survey: Ochratoxin A in European special wines. Food Chemistry, 108, 593-599.

Varga, J., Kiss, R., Mátrai, T., \& Téren, J. (2005). Detection of ochratoxin A in Hungarian wines and beers. Acta Alimentaria, 34, 381-392.

Varga, J., \& Kozakiewicz, Z. (2006). Ochratoxin A in grapes and grape-derived products. Trends in Food Science \& Technology, 17, 72-81.

Varga, V., Kocsubé, S., Szigeti, G., Baranyi, N., \& Tóth, B. (2015). Aspergillus mycotoxins In R. R. M. Paterson, \& N. Lima (Eds.). Molecular biology of food and water borne mycotoxigenic and mycotic fungi (pp. 165-186). Baton Rouge: CRC Press.

Venâncio, A., \& Paterson, R. (2007). The challenge of mycotoxins. In A. McElhatton, \& R. J. Marshall (Eds.). Food safety - A practical and case study approach (pp. 24-47). New York: Springer.

Visconti, A., Perrone, G., Cozzi, G., \& Solfrizzo, M. (2008). Managing ochratoxin A risk in the grape-wine food chain. Food Additives and Contaminants, 25, 193-202.

White, M. A., Diffenbaugh, N. S., Jones, G. V, Pal, J. S., \& Giorgi, F. (2006). Extreme heat reduces and shifts United States premium wine production in the 21st century. Proceedings of the National Academy of Sciences of the United States of America, 103, 11217-11222.

Wright, S. A. I. (2015). Patulin in food. Current Opinion in Food Science, 5, 105-109.

Wu, J., Tan, Y., Wang, Y., \& Xu, R. (2011). Occurrence of ochratoxin A in wine and beer samples from China. Food Additives and Contaminants, 4, 52-56.

Zhang, X., Li, Y., Wang, H., Gu, X., Zheng, X., Wang, Y., ... Zhang, H. (2016). Screening and identification of novel ochratoxin a-producing fungi from grapes. Toxins, 8, 1-14.

Zhong, Q. D., Li, G. H., Wang, D. B., Shao, Y., Li, J. G., Xiong, Z. H., \& Wu, Y. N. (2014). Exposure assessment to ochratoxin A in Chinese wine. Journal of Agricultural and Food Chemistry, 62, 8908-8913.

Zimmerli, B., \& Dick, R. (1996). Ochratoxin A in table wine and grape-juice: Occurrence and risk assessment. Food Additives and Contaminants, 13, 655-668. 